\title{
Isotopic Evidence of Human Mobility and Diet in a Prehistoric/Protohistoric Fijian Coastal Environment (c. 750-150 BP)
}

\author{
Christina Stantis, ${ }^{*}$ Hallie R. Buckley, Rebecca L. Kinaston, Patrick D. Nunn, Klervia Jaouen, and \\ Michael P. Richards
}

University of Otago, Dunedin 9012, New Zealand

KEY WORDS Fiji; carbon isotope analysis; nitrogen isotope analysis; 87Sr/86Sr; child-

hood diet

\begin{abstract}
Objectives: Bourewa, on the southwest coast of Viti Levu in Fiji, is a multi-period site that contained burials dated to the later Vuda Phase (750-150 BP), a period of climatic fluctuations that potentially impacted the availability of food resources. We aim to investigate diet and movement at this site during a time of possible ecological pressure and political change.

Materials and Methods: We analyzed $\delta^{13} \mathrm{C}, \delta^{15} \mathrm{~N}$, and ${ }^{87} \mathrm{Sr} /{ }^{86} \mathrm{Sr}$ of these Vuda Phase individuals $(n=25)$ interred at the site. By analyzing dentin and bone, both childhood diet and the diet within the past few years of adults' lives were examined.

Results: The paleodietary results suggested that adult diets consisted largely of low trophic level marine organisms. Dentin and bone isotopic values differed significantly: childhood diet involved consumption of more higher trophic level terrestrial foods. Most individuals displayed ${ }^{87} \mathrm{Sr} /{ }^{86} \mathrm{Sr}$ ratios expected of people living along a marine coastline. However, a few individuals displayed ${ }^{87} \mathrm{Sr} /{ }^{86} \mathrm{Sr}$ ratios and paleodietary values $\left(\delta^{13} \mathrm{C}_{\text {dentin }}, \delta^{15} \mathrm{~N}_{\text {dentin }}\right)$ suggestive of living further inland or consuming a more terrestrial-based childhood diet.

Discussion: The results are compared with past studies of sites from Fiji and nearby archipelagoes, placing our interpretations into a wider regional context. The Bourewa community appears to have consumed more low trophic level marine foods than any nearby site, possibly because terrestrial foods were more difficult to acquire. Interpreting the childhood diet is challenging due to the paucity of ethnohistoric literature on Fijian childhood; small meals outside of communal mealtimes or feeding children terrestrial animal protein as a means of cultural buffering are potential explanations. Am J Phys Anthropol 000:000-000, 2015. (c) 2015 Wiley Periodicals, Inc.
\end{abstract}

The isotopic analysis of human remains can provide information about past human diet and mobility. These studies have the potential to directly address many of the questions regarding how people subsisted and to what degree they were mobile in the past. Comparatively few isotope analyses have been carried out on prehistoric human remains in the tropical Pacific islands and Fiji in particular (see below) compared with other world regions, yet such analyses have the potential to answer many unresolved questions about prehistoric subsistence strategies and mobility in this region.

Given its size and environmental diversity, there have been relatively few archaeological studies in the Fijian archipelago (Nunn et al., 2003; Sand, 2007). Most stable isotope studies in Fiji have focused on smaller islands such as Cikobia (Valentin et al., 2006), Moturiki (Nunn et al., 2007), Waya (Field et al., 2009), and the Lau Group (Jones and Quinn, 2009; Jones et al., 2015) and only one of these studies (Valentin et al., 2006) is based on inhumations providing demographic context. The only published isotopic data of archaeologically-derived humans from Viti Levu, the main island of Fiji, are three samples of bone from the Nokonoko and Bukusia sites in the Sigatoka Valley (Field et al., 2009) and one individual from the Sigatoka Sand Dunes (Leach et al., 2003), although an unpublished Master's thesis also contains isotopic data from burials in the Sigatoka Sand
Dunes (Phaff, 2012). The relative scarcity of analyzed human remains on Viti Levu may be because of the difficulty of identifying sites along the island's geomorphologicallydynamic coasts, particularly where large rivers meet the ocean; the exception is at the site of Sigatoka where a large dunefield created environments suited to human settlement in its lee (Burley and Clark, 2003; Burley, 2003; Anderson et al., 2006).

It has been argued that the transition, approximately 700 to $600 \mathrm{BP}$, between the Little Climatic Optimum (or Medieval Warm Period or Medieval Climate Anomaly) and the Little Ice Age was marked by a period of comparatively rapid cooling and sea-level fall that abruptly and significantly reduced the food-resource base on which coastal dwellers throughout the Pacific depended

\footnotetext{
Grant sponsor: Max Planck Society.

*Correspondence to: Christina Stantis, University of Otago, Dunedin, New Zealand 9012. E-mail: chris.stantis@gmail.com
}

Received 1 May 2015; revised 1 October 2015; accepted 5 October 2015

DOI: 10.1002/ajpa.22884

Published online 00 Month 2015 in Wiley Online Library (wileyonlinelibrary.com). 
(Nunn and Britton, 2001; Nunn, 2007). Sea-level fall is proposed to have exposed nearshore reef surfaces, reduced water circulation and aeration in nearshore (reef-bounded) lagoons, and lowered island water tables, all of which would have reduced the availability of both wild and cultivated foods. Datasets in support of this model have been generated for the Sigatoka Valley, close to Bourewa, and for the northern coast of Viti Levu island (Kumar et al., 2006; Nunn, 2012a,b).

In addition to sea-level fall, the cooling that signaled the start of the Little Ice Age (around 550-600 BP) was accompanied by an increase in climate variability as proxied by frequency and strength of El Niño-Southern Oscillation (ENSO) events. Increased climate variability of this kind saw increases in episodes of drought and flooding which would have severely impacted horticultural production (Terry et al., 2001; Field and Lape, 2010). During the Little Ice Age, which ended about 150 $\mathrm{BP}$, most settlements in Fiji were inland, upslope and either fortified or in defensible locations: a marked contrast to the previous $\sim 2,000$ years of generally coastaltethered settlement (Clark and Anderson, 2009). This period of Fiji prehistory has long been recognized as the Vuda Phase, a time quite different to earlier phases because of the sharply-reduced coastal settlement with evidence for widespread conflict and constrained diets (Field, 2004; Field and Lape, 2010). Stable isotope analyses of carbon and nitrogen in human skeletal remains presented in this article will help us understand the nature of livelihoods during the Vuda Phase in Fiji.

This study focuses on human remains from the last millennium (750-150 BP) that were recovered from Bourewa, a Lapita-age settlement on the southwest coast of Viti Levu island. The human remains were cut into the settlement, from the more recent Vuda Phase of Fiji prehistory (900-150 BP) (Green, 1963; Frost, 1979). The Vuda Phase is distinguished archaeologically from earlier phases by the evidence for conflict, shown by increased fortification and competition for resources, that has been interpreted throughout tropical Pacific societies as a response to resource depletion driven ultimately by climate change (Frost, 1979; Best, 1984; Anderson, 2002; Nunn, 2007; Field and Lape, 2010).

This study has two main aims. First, we aim to understand individual human mobility in Vuda Phase Bourewa in order to consider which factors may have affected migration, such as cultural adaptations to environmental pressures. If nonlocals are identified from our analyses, we hypothesize a greater proportion of these individuals will be females because traditional society in Fiji is patrilocal (Becker, 1995; Jones, 2009). Our second aim is to characterize the childhood $(\sim 5-10$ years of age $)$ and adult diet of the Bourewa population. We examine whether there were large differences in diet between males and females and adults and subadults that may inform about dietary patterns during the Vuda phase, a time of cultural change and potential resource stress resulting from climate change. As a synchronic skeletal assemblage, we cannot directly compare the Vuda-phase individuals to earlier or later time periods to test the hypothesis that climatic fluctuations affected diet or mobility. However, the archaeological and paleoclimatic evidence places the Bourewa individuals within a dynamic period in Fijian prehistory and isotope analyses provide a direct means of understanding diet and mobility during this time.

\section{THE ISLAND OF VITI LEVU AND THE SITE OF BOUREWA}

Viti Levu, the largest island in the Republic of Fiji $\left(10,388 \mathrm{~km}^{2}\right)$, is geologically diverse and exhibits a wide variety of microclimates due to its rugged terrain, variable rainfall, and lithological complexity (Rodda, 1967). The Rove Peninsula in southwest Viti Levu is composed largely of pebbly silt-clay soils overlying marl and limestone bedrock. The southwest coast of the Rove Peninsula, where the site of Bourewa is located, is dominated by a broad fringing reef up to $3 \mathrm{~km}$ wide while the southeast coast contains a deepwater bay, known as the Natadola Harbor (Fig. 1). Mangrove forests dominate the northern portion of the Rove Peninsula and are likely to have developed only in the second half of the last millennium (Nunn et al., 2004; Nunn, 2009).

The site of Bourewa mainly dates to the early Lapita period, but also contains intrusive burials from the later Vuda Phase. The site was excavated over seven field seasons between 2003 and 2009 (Nunn et al., 2004; Nunn and Petchey, 2013). Radiocarbon dating of shell and charcoal from the lowest layers establish the occupation of Bourewa by at least $2800 \mathrm{BP}$, making the site as one of the earliest settlements in Fiji (Nunn and Petchey, 2013).

Occupation at Bourewa, which lasted several hundred years, ended around $2500 \mathrm{BP}$, yet cut into its occupation layers were sixteen burial pits from a later period with no grave goods. No osteological analyses have been performed on this assemblage other than a study comparing oral disease prevalence to other nearby assemblages (Stantis et al., in press). Thirteen of the 25 individuals included in this isotopic study were subjected to accelerator mass spectrometry (AMS) radiocarbon dating (Table 1) (Nunn, 2007). These individuals as a group displayed a date range between 750 and $0 \mathrm{BP}$. Although some of the individuals are radiocarbon dated to the Historic Period (150 BP-50 BP) the lack of historic grave goods and/or local knowledge of these burials strongly suggests that they were more likely prehistoric but some individuals may have been from the protohistoric period. The range of dates for the 13 individuals (Fig. 2) cannot be meaningfully correlated with either location of burial within the site, depth or orientation of interment (Fig. 3).

\section{STABLE ISOTOPES IN DIETARY RECONSTRUCTION}

The analysis of the carbon and nitrogen stable isotope ratios of bone and dentin collagen is a well-established tool for understanding diet in humans and other animals (Ambrose and Krigbaum, 2003; Hedges et al., 2007; Katzenberg, 2007; Schoeninger, 2010). Carbon primarily enters the food web through primary producers, and thus most of the differences in carbon isotopic values $\left(\delta^{13} \mathrm{C}\right)$ between food webs arise from the varying $\delta{ }^{13} \mathrm{C}$ values of autotrophs (Lee-Thorp et al., 1989; Sharp, 2007). Carbon stable isotope ratios of bone and dentin collagen are used to differentiate between the consumption of terrestrial $\mathrm{C}_{3}$ plants and marine foods in past populations (DeNiro and Epstein, 1978b; Lee-Thorp et al., 1989; Hoefs, 2009). Terrestrial $\mathrm{C}_{3}$ plants use the Calvin cycle to fix carbon from atmospheric $\mathrm{CO}_{2}$ and will display a $\delta^{13} \mathrm{C}$ range between -33 and $-23 \%$ (Marshall et al., 2007; Sharp, 2007). Marine autotrophs generally 

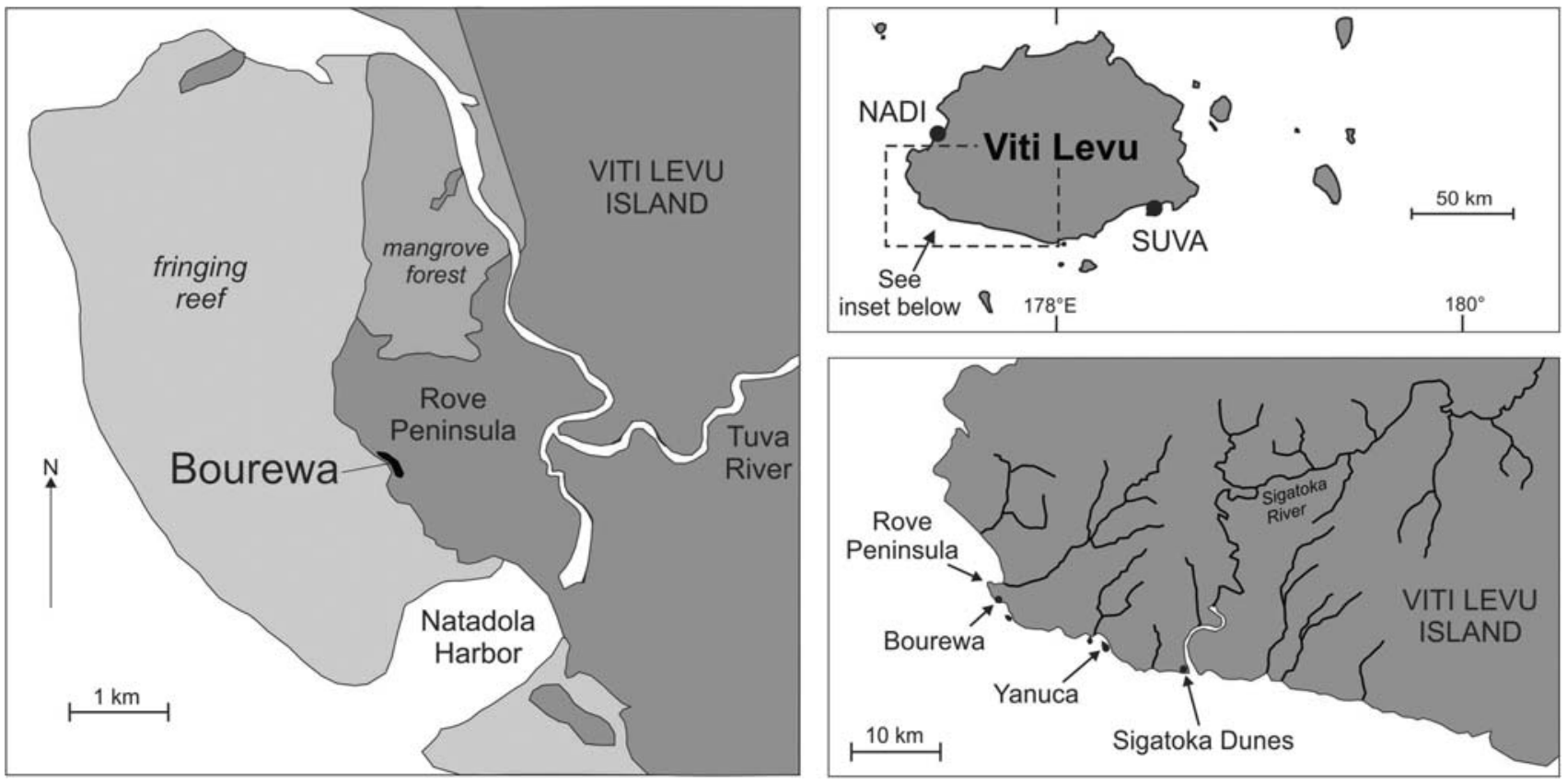

Fig. 1. Location of the Bourewa archaeological site on the Rove Peninsula in southwest Viti Levu Island, Fiji. Map on the top right shows the islands of central Fiji and the location of the inset of southwest Viti Levu Island on the bottom right. The map on the left shows the location of the Bourewa site as well as the adjacent fringing coral reef, nearby mangroves and harbor. [Color figure can be viewed in the online issue, which is available at wileyonlinelibrary.com.]

TABLE 1. Radiocarbon dates of the intrusive burials from Bourewa analyzed isotopically for this study ( $n=13$ individuals)

\begin{tabular}{|c|c|c|c|c|c|c|c|c|c|}
\hline $\begin{array}{l}\text { Burial } \\
\# \\
\end{array}$ & $\begin{array}{c}\text { Laboratory } \\
\#\end{array}$ & $\delta^{13} \mathrm{C}$ & $\delta^{15} \mathrm{~N}$ & $\begin{array}{c}\% \\
\text { Marine } \\
\end{array}$ & D14C & $\begin{array}{c}\text { Conventional } \\
\text { age (yr BP) }\end{array}$ & $\begin{array}{c}\text { Calibrated age } \\
(\text { cal yr BP })\end{array}$ & $\begin{array}{c}\text { Calendar } \\
\text { age }\end{array}$ & $\begin{array}{c}\text { Probability } \\
(\%)\end{array}$ \\
\hline 03 & Wk-17438 & -14.67 & 8.13 & 70 & $-11.7 \pm 3.6$ & $283 \pm 32 \mathrm{BP}$ & $138-0$ cal BP & $\mathrm{AD} 1812-1950$ & 95.4 \\
\hline 04 & Wk-17442 & -16.12 & 7.96 & 54 & $-96.3 \pm 3.0$ & $982 \pm 30 \mathrm{BP}$ & $750-560 \mathrm{cal} \mathrm{BP}$ & $\mathrm{AD} 1200-1390$ & 95.4 \\
\hline 09 & Wk-17451 & -16.25 & 9.02 & 53 & $-8.8 \pm 4.0$ & $249 \pm 35 \mathrm{BP}$ & $250-0$ cal BP & AD $1700-1950$ & 95.4 \\
\hline 10 & Wk-17452 & -15.96 & 8.78 & 56 & $-33.4 \pm 3.2$ & $454 \pm 30 \mathrm{BP}$ & $330-50$ cal BP & AD $1620-1900$ & 93.9 \\
\hline 14 & Wk-17443 & -13.67 & 10.47 & 81 & $-28.7 \pm 3.5$ & $443 \pm 32 \mathrm{BP}$ & $250-0$ cal BP & AD $1700-1950$ & 95.4 \\
\hline 15 & Wk-17450 & -18.16 & 7.49 & 32 & $-20.9 \pm 3.5$ & $319 \pm 32 \mathrm{BP}$ & $300-50$ cal BP & $\mathrm{AD} 1650-1900$ & 86.1 \\
\hline 16 & Wk-17449 & -15.66 & 9.80 & 59 & $-31.9 \pm 3.2$ & $457 \pm 29 \mathrm{BP}$ & $320-50$ cal BP & AD $1630-1900$ & 93.8 \\
\hline 17 & Wk-17447 & -17.51 & 8.28 & 39 & $-33.4 \pm 3.3$ & $438 \pm 30 \mathrm{BP}$ & $450-140$ cal BP & AD $1500-1810$ & 95.4 \\
\hline 22 & Wk-17446 & -15.30 & 8.86 & 63 & $-37.2 \pm 3.7$ & $487 \pm 33 \mathrm{BP}$ & $340-50$ cal BP & AD 1610-1900 & 93.9 \\
\hline 23 & Wk-17439 & -16.04 & 8.89 & 55 & $-32.8 \pm 3.2$ & $441 \pm 30 \mathrm{BP}$ & $320-50$ cal BP & $\mathrm{AD} 1630-1900$ & 93.3 \\
\hline 24 & Wk-22827 & -14.60 & & & $-49.6 \pm 2.7$ & $409 \pm 37 \mathrm{BP}$ & $311-0$ cal BP & AD 1639-1950 & 95.4 \\
\hline 25 & Wk-22826 & -13.50 & & & $-56.6 \pm 2.5$ & $468 \pm 36 \mathrm{BP}$ & $335-0$ cal BP & AD $1615-1950$ & 95.4 \\
\hline 26 & Wk-17437 & -15.45 & 9.09 & 62 & $-37.1 \pm 3.5$ & $478 \pm 32 \mathrm{BP}$ & $330-50$ cal BP & AD $1620-1900$ & 93.6 \\
\hline
\end{tabular}

All dates from the University of Waikato Radiocarbon Dating Laboratory corrected using marine correction factor (DeltaR) of $11 \pm 26$ years (Petchey et al., 2008) and calibrated using the IntCal13 curve (Reimer et al., 2013) and a dietary correction involving $\delta{ }^{13} \mathrm{C}$ terrestrial/marine endpoints of $-21 /-12 \%$ (Petchey et al., 2014).

follow a $\mathrm{C}_{3}$ photosynthetic pathway, but many types of marine algae and cyanobacteria utilize sources of carbon with higher $\delta^{13} \mathrm{C}$ values, such as oceanic bicarbonate, which results in the correspondingly higher $\delta^{13} \mathrm{C}$ values of marine foodwebs (Fry et al., 1982; Schoeninger et al., 1983; Keegan and DeNiro, 1988). Freshwater autotrophs derive their carbon from a variety of sources including atmospheric $\mathrm{CO}_{2}$, dissolved $\mathrm{CO}_{2}$, soil bicarbonate, and carbon from organic detritus (Zohary et al., 1994). As a result freshwater fish bones have yielded more variable $\delta^{13} \mathrm{C}$ values than marine fish, ranging between -13 and $-25 \%$ (Katzenberg and Weber, 1999).

$\mathrm{C}_{4}$ plants, such as maize, millet, and sorghum display higher $\delta^{13} \mathrm{C}$ values compared with terrestrial $\mathrm{C}_{3}$ plants, typically between -16 and $-9 \%$, and thus largely over- lap in values with marine autotrophs (Sharp, 2007). There were very few edible $\mathrm{C}_{4}$ plants available during the prehistoric period in the tropical Pacific islands. The only cultivated terrestrial $\mathrm{C}_{4}$ plant consumed in Fiji would have been sugarcane (Saccharum officinarum) which forms a small part of modern horticultural pursuits (Jones, 2009).

Examining nitrogen stable isotope values $\left(\delta^{15} \mathrm{~N}\right)$ in bone collagen allows researchers to understand an organism's trophic level. There is a 3 to $5 \%$ stepwise enrichment between herbivores and the carnivores that prey upon them, with omnivores somewhere in between (Minagawa and Wada, 1984; Schoeninger and DeNiro, 1984; Bocherens and Drucker, 2003; O'Connell et al., 2012; Perkins et al., 2014). Marine food webs tend to be 
more complex with higher trophic levels. Used in conjunction with $\delta^{13} \mathrm{C}$ values, $\delta^{15} \mathrm{~N}$ values of human and animal bone collagen can be used to assess on organism's reliance on marine and terrestrial resources. There is also a stepwise enrichment of ${ }^{13} \mathrm{C}$ between trophic levels but the enrichment is often too small $(\sim 1 \%)$ to be easily observed except in controlled studies (DeNiro and

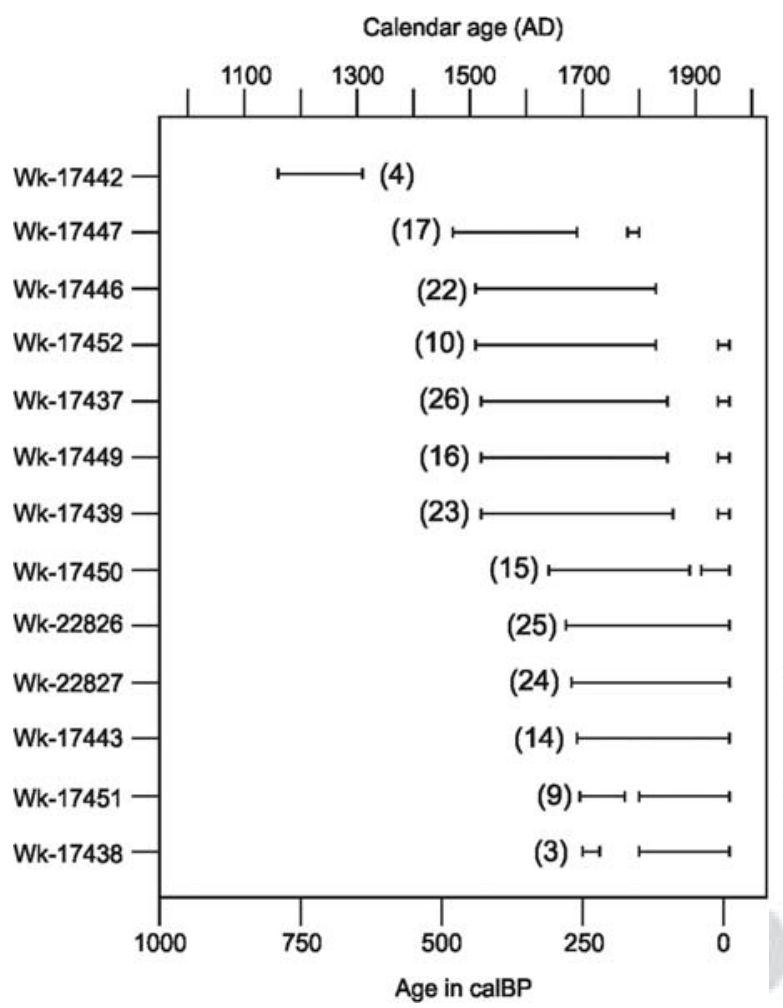

Fig. 2. Calibrated radiocarbon dates for Bourewa burials examined in this study. Burial numbers in parentheses.
Epstein, 1978b; Schoeninger and DeNiro, 1984; Bocherens and Drucker, 2003).

Macronutrients within the body (i.e., carbohydrates, lipids, and proteins) are used to synthesize the tissues of the body, including bone collagen (DeNiro and Epstein, 1978a; Tieszen et al., 1983). Dietary carbohydrates and lipids are metabolized for energy and their carbon is used in the synthesis of bone bioapatite (Krueger and Sullivan, 1984). Dietary amino acids are preferentially routed for the synthesis of bone and dentin collagen (Krueger and Sullivan, 1984; Lee-Thorp et al., 1989). As such, bone collagen $\delta^{13} \mathrm{C}$ values are largely representative of the protein portion of an individual's diet though other macronutrients may also provide carbon for collagen synthesis (Kellner and Schoeninger, 2007; Froehle et al., 2010, 2012). The $\delta^{15} \mathrm{~N}$ values of bone collagen are solely representative of dietary protein because carbohydrates and lipids do not contain nitrogen. If there is a substantial amount of high protein foods in the diet, low-protein foods may be under-represented when examining the isotopic composition of collagen (Ambrose, 1993; Ambrose and Norr, 1993; Fernandes et al., 2012).

By analyzing different skeletal tissues from adults, researchers can examine both an individual's diet within the last few years of death and their childhood diet (Schroeder et al., 2009; Lamb et al., 2014). The stable isotope ratios of bone collagen are representative of a person's diet during the last years of their life because bone is constantly remodeled (Hedges et al., 2007). Human teeth, however, do not remodel once formed (Hillson, 1996). The examination of dentin collagen gives a "snapshot" of an individual's childhood diet. More specifically, dentin collagen of an adult records the diet of an individual who survived childhood. A time span roughly between 5 and 10 years of age can be captured by sampling from the roots of permanent premolars and molars, as detailed in the methods section below (Hillson, 1996). With only one subadult in the assemblage (Burial 15), the analysis of dentin collagen allows the investigation of childhood diet within this population.

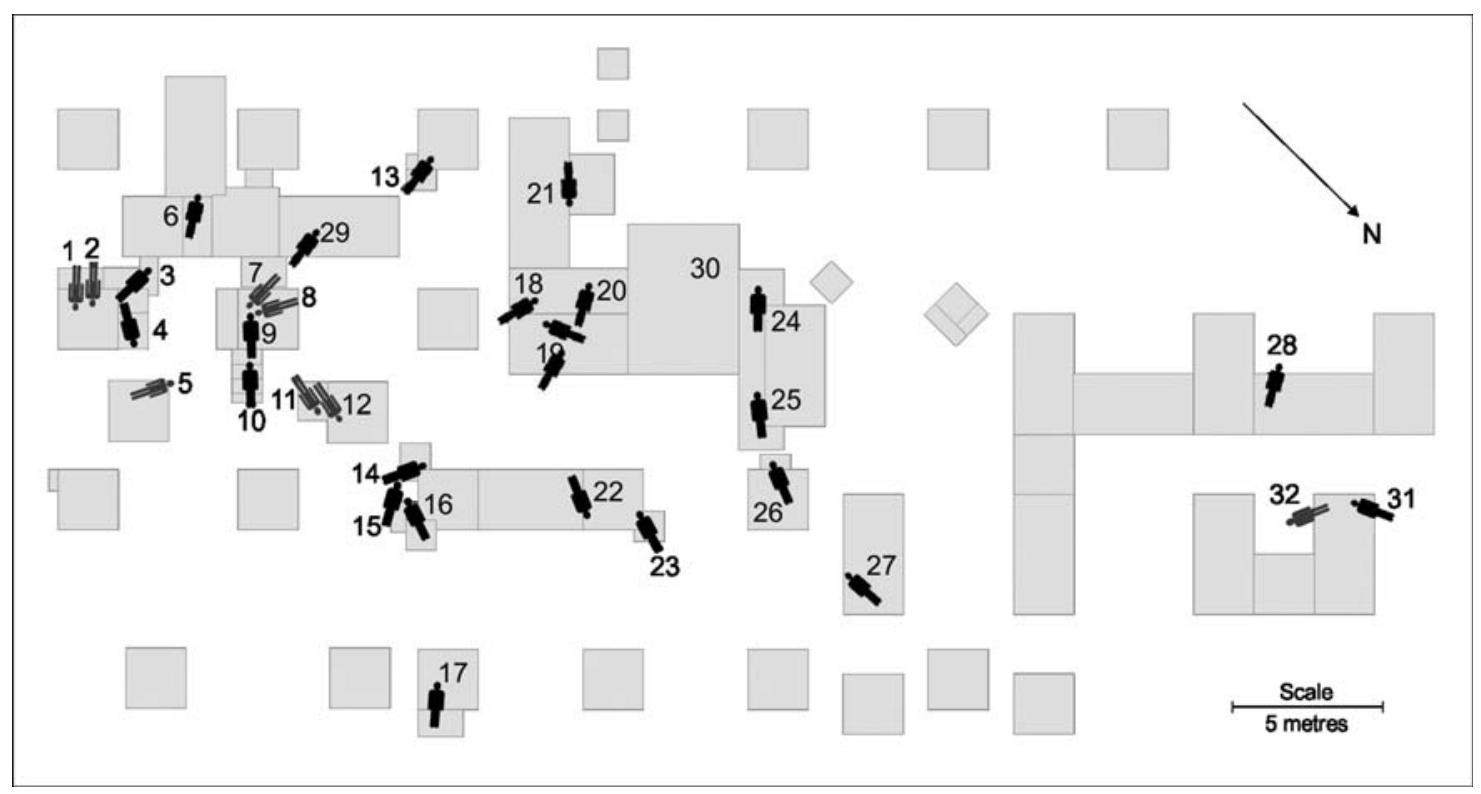

Fig. 3. Location and orientation of Bourewa inhumations. Those individuals analyzed for this study are shown in bold. Note that only the central part of the Bourewa site is shown; more details are in Figure 3 of Nunn and Petchey (2013). 
Teeth formed during breastfeeding will display elevated $\delta^{15} \mathrm{~N}$ values due to the infant feeding from a higher trophic level (Tsutaya and Yoneda, 2015). While a child between 5 and 10 years of age could theoretically still have breast milk as part of their diet, and no assumptions are made about expected breastfeeding practices in prehistoric Fiji, the age of complete weaning in nonforaging societies is around the age of two (Barry and Paxson, 1971). Thus, the age range studied here is expected to not include breastfeeding.

\section{ISOTOPIC ANALYSIS OF MOBILITY}

Two isotopes of strontium, ${ }^{87} \mathrm{Sr}$ and ${ }^{86} \mathrm{Sr}$, are of interest for reconstructing the movement of humans and animals in the past. The interpretation of movement using strontium isotope analysis rests upon the assumption that the ${ }^{87} \mathrm{Sr} /{ }^{86} \mathrm{Sr}$ ratios of an individual's enamel will generally reflect the ${ }^{87} \mathrm{Sr} /{ }^{86} \mathrm{Sr}$ ratios of the underlying geology in which they lived during childhood (Montgomery et al., 2005; Bentley, 2006). Strontium has an atomic radius similar to the atomic radius of calcium $(215 \mathrm{pm}$ and $197 \mathrm{pm}$, respectively) and belongs to the same periodic group of alkaline earth elements. As a result, strontium readily replaces calcium in minerals, including calcium carbonate in chalk, limestone, and marble, and calcium in the bones and teeth (Bentley, 2006; Burton, 2008). Erosion of the underlying geological formations is the major contributor to the ${ }^{87} \mathrm{Sr} /{ }^{86} \mathrm{Sr}$ ratios of the soil, and plants display ${ }^{87} \mathrm{Sr} /{ }^{86} \mathrm{Sr}$ values nearly identical to the soil in which they grow (Evans et al., 2010). Other sources such as precipitation, sea-spray, and loess can also influence the local strontium isotopic composition of living organisms in an area, known as the biologically available or bioavailable strontium (Bentley, 2006).

Strontium isotopic analysis in archaeologically-derived bone can be affected by diagenesis, but tooth enamel is more resistant to diagenetic alteration (Price et al., 1992; Chiaradia et al., 2003; Trickett et al., 2003; Bentley, 2006) and is therefore preferred. The strontium isotope signature in tooth enamel from permanent teeth is representative of where a person lived during the time of tooth formation (i.e., childhood or adolescence, depending on the tooth sampled) (Bentley, 2006).

\section{DIET IN PREHISTORIC FIJI}

Ethnographic observations on the (outer) Lau islands found that starchy fruits and root vegetables (kakana dina, or "true food") constitute roughly 70 to $80 \%$ of a typical person's daily foods (Jones, 2009). This reliance on farinaceous root vegetables as the basis of subsistence is typical throughout the tropical Pacific islands (Barrau, 1961; Pollock, 1992). Bony fish were reportedly eaten every day by those interviewed, while turtle, chicken (Gallus gallus domesticus), and pig (Sus scrofa) were saved for special occasions. Taro (Colocasia esculenta), sweet potatoes (Ipomoea batatas), yams (Dioscorea spp.), giant taro (Alocasia macrorrhizos), and bananas (Musa spp.) were grown in family gardens with wild yams available in the interior forests and breadfruit (Artocarpus altilis) on the hill slopes and in the village gardens (Jones, 2009; p 109). As is typical throughout most Pacific islands, women and children are the primary collectors of inshore marine resources on Fiji, while men fish for reef and deeper pelagic species (Jones, 2009; Jones and Quinn, 2009). The inhabitants of Viti Levu and other continental islands, unlike smaller islands in
Remote Oceania, routinely had access to a variety of coastal zones for shellfish gathering, not just coral reef environments. These included mud-flats, estuaries, sandy intertidal habitats, freshwater environments, and rocky shores (Szabó, 2001). Mollusk samples from Fijian archaeological sites spanning several islands and time periods display a wide diversity of species from a range of environments, suggesting broad-spectrum collection of marine organisms for consumption (Szabó, 2009).

Regarding animal domesticates and commensals, the chicken and rat (Rattus exulans and Rattus praetor) are found in the earliest settlement sites on Fiji (Worthy and Clark, 2009), with pigs and dogs (Canis lupus familiaris) appearing in later sites dating from $1000 \mathrm{BP}$ (Clark and Anderson, 2009). It may be that the initial colonizers had pigs and dogs but their remains have yet to be found, although it is also possible that these animals did not arrive with the first settlers and that a second migration wave brought these domesticates to Fiji for the first time (Worthy and Clark, 2009). As in many areas of the Pacific, earth ovens (lovo in Fijian) were the most common method of cooking food. These involved placing firewood in a stone-lined pit and, once the stones were sufficiently hot, placing the leaf-wrapped food in the pit. The food was then covered with more hot stones and then the pit buried with leaves or a mat and earth for several hours (Huebert et al., 2010). Ethnographic accounts record separate ovens made for men and women in Fiji, although there is no evidence that men and women ate different foods, as has been recorded in some other Pacific islands (Pollock, 1992; p 72).

Later prehistoric inhabitants of Viti Levu had varied economic and subsistence specializations (Clark and Anderson, 2009) with distinct territorial boundaries (Field, 2004, 2005). Coastal inhabitants of Viti Levu would be expected to have relied more heavily on marine resources than the inland inhabitants although recent research shows that the latter were prepared to make quite onerous journeys to access coastal foods (Robb and Nunn, 2014). Although no last-millennium settlement sites near Bourewa are known, it is reasonable to assume that the people buried there lived close enough to the coast to have routinely accessed its food resources. The broad fringing reef near Bourewa doubtlessly provided an abundance of marine resources for the Bourewa individuals as it continues to do so today (Nunn, 2009). Access to freshwater and arable soil is more difficult from the site, as is access to safe harbor for watercraft to a lesser degree (Nunn et al., 2004). This implies that use of the reef was likely an important part of the subsistence practice of any inhabitants on the Rove Peninsula. Microfossil evidence of taro and lesser yam in the Lapita-era deposits on Bourewa suggests that horticulture may have been practiced on the Rove Peninsula, at least in this earlier period, despite the adverse soil conditions (Horrocks and Nunn, 2007).

\section{GEOLOGICAL SETTING}

Geological formations can display a variety of strontium ratios, largely depending on their age of formation, and typically vary between 0.7020 and 0.750 (Faure and Powell, 1972). In the oceanic Pacific, most islands are either uplifted coral beds or volcanic in origin (Nunn, 1994, 1998). Coralline limestone rocks will exhibit ${ }^{87} \mathrm{Sr} /{ }^{86} \mathrm{Sr}$ values similar to the composition of the seawater in which they formed, thus fluctuating around 
0.7070 and 0.7090 within the last 500 million years (Veizer, 1989; McArthur, 1994). Volcanic materials will display a lower ${ }^{87} \mathrm{Sr} /{ }^{86} \mathrm{Sr}$ ratio between 0.7020 and 0.7040 (Bentley, 2006). Geological strontium studies show the Fiji islands ranging between 0.7029 and 0.7090 (Gill, 1984; Bromfield and Renema, 2011) as is typical of an archipelago composed of both uplifted coral and volcanic islands. Other than the underlying geology, sea spray from marine-derived precipitation can also contribute to the local bioavailable strontium signature (Bentley, 2006). The circulation of the ocean ensures it has a homogenous ${ }^{87} \mathrm{Sr} /{ }^{86} \mathrm{Sr}$ ratio, 0.7092, since the beginning of the Holocene era (Elderfield, 1986; Veizer et al., 1997).

The use of geological data as proxies for understanding human mobility cannot always be interpreted unambiguously (Laffoon et al., 2012). It is often difficult to predict the mixing effects in any area where multiple bedrocks with different ${ }^{87} \mathrm{Sr} /{ }^{86} \mathrm{Sr}$ ratios and varying weathering rates exist (Bentley, 2006). In coastal areas, the bioavailable strontium may be heavily influenced by marine-derived precipitation and sea spray (Whipkey et al., 2000) and, potentially, marine-based diets (Burton and Price, 1999; Bentley et al., 2007) in addition to the underlying bedrock. Thus, empirical assessments of the biosphere have been found to be a more accurate predictor of what a local individual's ${ }^{87} \mathrm{Sr} /{ }^{86} \mathrm{Sr}$ ratio is likely to be (Evans et al., 2010). With this method, recording ${ }^{87} \mathrm{Sr} /{ }^{86} \mathrm{Sr}$ ratios in plants or low-mobility animals is an effective way of establishing a local baseline because there is no need to account for mixing effects. Plants (Evans et al., 2010; Kinaston et al., 2014a), pigs (Bentley and Knipper, 2005), dogs (Kinaston et al., 2013b), and snails (Evans et al., 2009) have all been used for this purpose.

For this study we use strontium isotope values of individuals that are two standard deviations from the assemblage mean as indicative of nonlocals following Price et al. (2002). This method has been used in other prehistoric Pacific studies (Bentley et al., 2007; Shaw et al., 2009, 2010). The use of two standard deviations as a means of identifying nonlocals can be influenced by small sample size or when variation in the ${ }^{87} \mathrm{Sr} /{ }^{86} \mathrm{Sr}$ ratios of the local geology is far broader or smaller than the scope of two standard deviations within the skeletal assemblage (Szostek et al., 2015). However, in the absence of published data for bioavailable strontium ratios for Fiji, this is currently the best means of identifying nonlocals in the Bourewa skeletal sample.

\section{MATERIALS AND METHODS}

The Bourewa assemblage was examined in the Anthropology Laboratory in the Department of Anatomy, University of Otago (New Zealand). Completeness of the burials was variable. Some skeletons were nearly perfectly preserved, while others are incomplete due to postdepositional disturbance (i.e., plowing of the soil). In most cases the preservation of the bone tissue was excellent. From the Bourewa assemblage, 23 bones and 17 teeth in total were sampled from 25 individuals. Sex and age estimation of the individuals was conducted by CS using standards outlined in Buikstra and Ubelaker (1994).

\section{Strontium analysis}

Tooth enamel preparation was conducted by RLK at the Max Planck Institute for Evolutionary Anthropology (Leipzig, Germany). One tooth from each individual was chosen. Permanent second molars and first or second premolars were preferentially chosen, although a permanent canine and a permanent second incisor were sampled for two individuals. The premolars and second molar (upper and lower) complete crown formation between five and eight years of age (Massler and Schour, 1940; Hillson, 1996).

A small piece of enamel $(5-10 \mathrm{mg})$ from each tooth was sandblasted to remove surface impurities and then a small piece was cut away with a dental drill. Any dentin was removed with a diamond-tipped burr. After being sonicated with $1 \mathrm{~mL}$ acetone and rinsed three times with water, samples were purified using the ion exchange method outlined in Deniel and Pin (2001).

The samples, reference standard SRM 1486 (bone meal), and blanks were analyzed using a Thermo Fisher Neptune $^{\text {TM }}$ plasma ionization multicollector mass spectrometer (PIMMS) by K.J. at the Max Planck Institute for Evolutionary Anthropology (Leipzig, Germany). Repeated measurement of international standard SRM 987 was used to ensure accuracy of data, and samples were adjusted using the published value of SRM 987, 0.710240 (Terakado et al., 1988; Johnson et al., 1990). ${ }^{87} \mathrm{Rb}$ and ${ }^{86} \mathrm{Kr}$ interferences were corrected by measuring ${ }^{85} \mathrm{Rb},{ }^{83} \mathrm{Kr}$, and ${ }^{82} \mathrm{Kr}$. Instrument mass bias was normalized by measuring ${ }^{88} \mathrm{Sr}$ and using the natural ${ }^{88} \mathrm{Sr} /{ }^{86} \mathrm{Sr}$ ratio of 8.375209 (Nier, 1938).

\section{Carbon and nitrogen analysis}

Samples of cortical bone fragments weighing between approximately 1,200 and 1,400 $\mathrm{mg}$ were taken from each individual. Bones displaying pathological changes were not sampled as changes in the metabolic pathways of diseased tissues may affect isotopic composition (Katzenberg and Lovell, 1999; Olsen et al., 2014).

For tooth sampling, permanent second molars (maxillary or mandibular, any side) were preferentially chosen as the primary sample over any other tooth type. If second molars were not available, permanent premolars (first or second) were chosen, followed by first molars. Permanent second molars and the premolars have similar formation and eruption times (Hillson, 1996). Deciduous teeth were excluded from this study, as deciduous teeth begin formation in utero and the stable isotope ratios of these teeth would be affected by the maternal isotopic composition (Fuller et al., 2003; Beaumont et al., 2013). Anterior teeth (canines and incisors) were avoided as they form earlier in a human's lifetime (Hillson, 1996), when breastfeeding and complementary foods may have an effect on the isotopic composition of these teeth (Katzenberg et al., 1996; Richards et al., 2002). First molars form earlier than second molars and premolars (Moorrees et al., 1963). For first molars, the root half $\left(R_{1 / 2}\right)$ with the apex $(A)$ was used for isotopic analysis; for the premolars and second molar the $R_{1 / 2}$ closer to the cement-enamel junction (CEJ) was sampled. This created a roughly equivalent time span captured in each root, between $\sim 5$ and 10 years of age (Hillson, 1996).

After photographing and removing the outer surface of the bone and teeth samples, collagen was extracted and purified using the modified Longin method (Longin, 
1971; Brown et al., 1988; Collins and Galley, 1998). The samples were demineralized in $0.5 \mathrm{M} \mathrm{HCl}$ at $4^{\circ} \mathrm{C}$ (changing the acid regularly) and gelatinized in $\mathrm{pH} 3$ solution at $70^{\circ} \mathrm{C}$ for $48 \mathrm{~h}$. After filtering $\left(5-8 \mu \mathrm{m}\right.$ Elkay Ezee ${ }^{\circledR}$ mesh filter) and ultrafiltering (Amicon Ultra-0.5 Centrifugal Filter Units with Ultracel-30 membranes), the samples were frozen, then lyophilized for $48 \mathrm{~h}$ and weighed.

Bone collagen preparation was conducted by R.L.K. at the Max Planck Institute for Evolutionary Anthropology (Leipzig, Germany). C.S. prepared the dentin collagen samples using the same protocol as for the bone collagen. Mass spectrometer analyses were conducted at two different laboratories. The bone collagen carbon and nitrogen stable isotope analysis was conducted at the Max Planck Institute for Evolutionary Anthropology. The dentin samples, prepared later, were analyzed by Iso-Analytical Limited (Cheshire, UK).

At the Max Planck Institute, all samples were analyzed in duplicate. Carbon and nitrogen stable isotope values were measured simultaneously using a Flash EA 2112 coupled to a DeltaXP continuous-flow isotope-ratiomonitoring mass spectrometer. Repeated measurements of working standards EVA-0009 (methionine), SRM 1577b (bovine liver), IAEA-N-1 and -N-2 (ammonium sulfate), IAEA-CH-6 (sucrose), and IAEA-CH-7 (polyethylene) were interspersed throughout the archaeological samples to correct the carbon and nitrogen isotope data. The analytical precision of the $\delta^{13} \mathrm{C}$ and $\delta^{15} \mathrm{~N}$ measurements was $\pm 0.1 \%$.

At Iso-Analytical, carbon and nitrogen stable isotope ratios were measured using a Europa Scientific EA coupled to a Europa Scientific 20-20 IRMS in duplicate. IA-R042 was interspersed throughout the archaeological samples to ensure analytical precision. IA-R042 and a mixture of IA-R006 and IA-R046 were run as quality control check samples during analysis.

All dietary stable isotope ratios were standardized to the international reference standards for carbon and nitrogen (Vienna Pee Dee Belemnite [PDB] and Atmospheric Nitrogen [AIR], respectively). The carbon and nitrogen isotopic values and reported in parts per $\mathrm{mL}$ (\%) in $\delta$ notation, where $\delta=\left(\left[R_{\text {sample }}-R_{\text {standard }}\right] / R_{\text {stan- }}\right.$ dard $) \times 1,000$.

Collagen integrity indicators were examined to ensure preservation by examining the $\mathrm{C} / \mathrm{N}$ ratio and \%wt of carbon and nitrogen. Samples were deemed adequately preserved if they had a $\mathrm{C} / \mathrm{N}$ ratio between 2.9 and $3.6, \% \mathrm{wt}$ $\mathrm{C}$ between 15 and $47 \%$ and \%wt $\mathrm{N}$ between 5 and $17 \%$ (DeNiro, 1985; Ambrose, 1990; Ambrose and Norr, 1992; van Klinken, 1999). Any samples displaying $\mathrm{C} / \mathrm{N}, \% \mathrm{C}$, or $\% \mathrm{~N}$ values outside these parameters were excluded from statistical analysis. Bone collagen samples from two individuals were excluded: Burial 17 displayed C:N higher than 3.6 and Burial 19 had \%wt $\mathrm{C}$ higher than $47 \%$. All tooth samples met the criteria for collagen integrity and were included in analysis and interpretation.

In order to place the Bourewa individuals within the tropical Pacific island food web, comparison of the human $\delta^{13} \mathrm{C}$ and $\delta^{15} \mathrm{~N}$ values to a baseline of plants and animals was necessary. Unfortunately, no faunal samples from Bourewa were available for analysis and instead baseline data collected for comparison in the nearby archipelago of Vanuatu and other published Pacific island studies were utilized (Kinaston et al., $2014 \mathrm{a}, \mathrm{b})$. Although isotopic values of pigs and other domesticates from other Pacific sites are available (Allen and Craig, 2009; Kinaston et al., 2014a,b, 2015), pigs and other domesticates were not included in the dietary baseline. Different animal husbandry practices from island to island (Oliver, 1989) may result in variation in the domesticate isotope values and affect the interpretation of the human dietary results.

\section{RESULTS}

The ${ }^{87} \mathrm{Sr} /{ }^{86} \mathrm{Sr}, \delta^{13} \mathrm{C}$, and $\delta^{15} \mathrm{~N}$ results are presented in Table 2 along with the demographic information. Twenty-one bone and 16 tooth collagen samples met the criteria for collagen integrity and these $\delta^{13} \mathrm{C}$ and $\delta^{15} \mathrm{~N}$ values are included in the results and discussion. The descriptive statistics of the isotopic findings are presented in Table 3. The $\delta^{13} \mathrm{C}_{\text {bone values ranged between }}$ $-17.2 \%$ and $-13.1 \% \quad($ mean $=-15.1 \% \pm 1.0)$ and the $\delta^{13} \mathrm{C}_{\text {dentin }}$ values were between $-18.1 \%$ and $-14.4 \%$ $($ mean $=-16.2 \% \pm 1.1) . \delta^{15} \mathrm{~N}_{\text {bone }}$ values ranged between $6.8 \%$ and $9.9 \%($ mean $=8.6 \% \pm 0.8)$ and the $\delta^{15} \mathrm{~N}_{\text {dentin }}$ values ranged between $7.6 \%$ and $10.5 \%$ (mean$=9.1 \% \pm 0.8)$. The $\delta^{13} \mathrm{C}$ bone and $\delta^{15} \mathrm{~N}_{\text {bone values dis- }}$ played a statistically significant positive correlation, $r(27)=0.87, P<0.001$, as did the $\delta^{13} \mathrm{C}$ dentin and $\delta^{15} \mathrm{~N}_{\text {den- }}$, tin, $r(15)=0.84, P<0.001$. Figures 4 and 5 display the bone and dentin paleodietary results.

Seventeen individuals had both cortical bone and teeth available for analysis. Following Reitsema and Vercellotti (2012), the differences between dentin and bone values of carbon are displayed as a value of $\delta^{13} \mathrm{C}$ dentin $-\delta^{13} \mathrm{C}$ bone, or $\Delta^{13} \mathrm{C} . \Delta^{15} \mathrm{~N}$ is calculated in a similar manner. The $\Delta^{13} \mathrm{C}$ and $\Delta^{15} \mathrm{~N}$ results are presented in Figure 6. The mean $\Delta^{13} \mathrm{C}$ was negative, at $-0.8 \% \pm 0.7$, and ranged from $-2.7 \%$ to 0.7 . These negative values indicate that $\delta^{13} \mathrm{C}$ bone values tended to be lower compared with $\delta^{13} \mathrm{C}$ dentin values. On average, females displayed a slightly larger difference between the dentin and bone $\delta^{13} \mathrm{C}$ values compared with males $(-1.3 \% \pm 0.5$ compared with $-1.0 \% \pm 0.4$ in males), although these differences were not significant using Student's t-tests, $t(6)=-0.43, P=0.683$.

Most individuals displayed slightly higher $\delta^{15} \mathrm{~N}_{\text {dentin }}$ compared with their $\delta{ }^{15} \mathrm{~N}_{\text {bone values (mean }}$ $\Delta^{15} \mathrm{~N}=0.7 \% \pm 0.6$ with a range between $-0.1 \%$ and 1.7 ). On average, females displayed a slightly smaller $\Delta^{15} \mathrm{~N}$ $(+0.5 \% \pm 0.3)$ compared with the mean $\Delta^{15} \mathrm{~N}$ for the males $(+0.8 \% \pm 0.4)$. As with $\Delta^{13} \mathrm{C}$, there were no significant differences between the sexes $(t(6)=-0.59, P=$ $0.580)$.

The isotopic compositions of the two tissues (bone and dentin) were compared using Wilcoxon rank-sum tests. Burial 15, the adolescent, was excluded from these comparisons. There were significant differences between bone and dentin $\delta^{13} \mathrm{C}$ values, $W(33)=900, z=2.6, P=$ 0.009 ; on average $\delta^{13} \mathrm{C}$ dentin values were $1.2 \%$ lower compared with $\delta^{13} \mathrm{C}$ bone values. The $\delta^{15} \mathrm{~N}_{\text {dentin }}$ values were $0.5 \%$ higher on average compared with the $\delta{ }^{15} \mathrm{~N}_{\text {bone }}$ values and these differences were also significant, $W(33)=900, z=-2.07, P=0.039$.

Cortical bone was sampled from six females and three males for the stable isotope analyses. There were no statistically significant differences between the sexes regarding $\delta{ }^{13} \mathrm{C}$ bone values when using a Kruskal-Wallis test, $(W(7)=16.67, z=-1.47, P=0.146)$ or $\delta^{15} \mathrm{~N}_{\text {bone }}$ values $(W(7)=16.67, z=-0.74, P=0.462)$. Teeth were sampled from six females and three males the for stable isotope analyses of dentin collagen and strontium 
C. STANTIS ET AL.

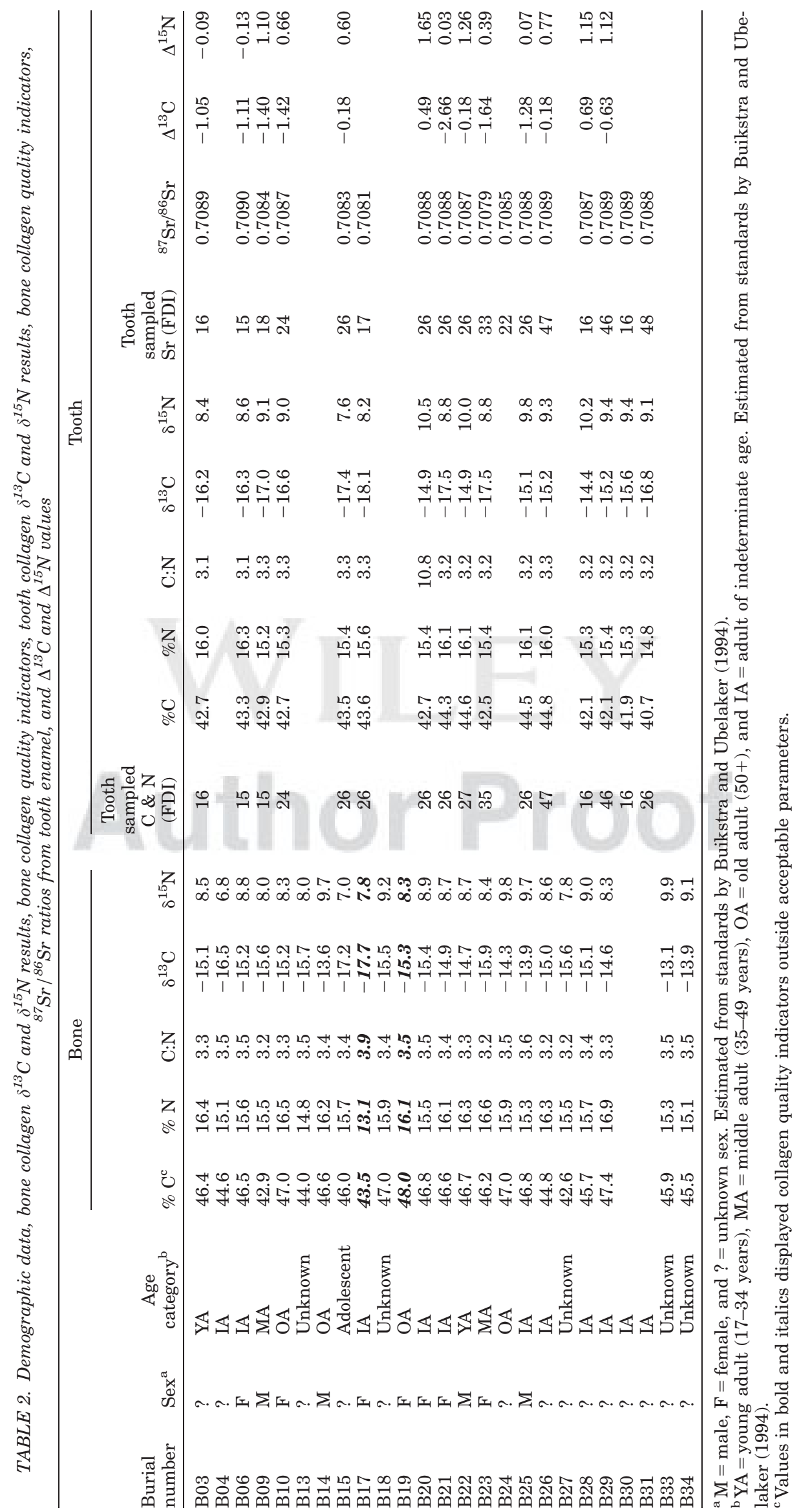


TABLE 3. Statistical summary of the isotopic results

\begin{tabular}{|c|c|c|c|c|c|c|c|c|c|c|c|c|c|}
\hline & \multicolumn{5}{|c|}{ Bone } & \multicolumn{8}{|c|}{ Tooth } \\
\hline & \multirow[b]{2}{*}{$n$} & \multicolumn{2}{|c|}{$\delta^{13} \mathrm{C}$} & \multicolumn{2}{|c|}{$\delta^{15} \mathrm{~N}$} & \multirow[b]{2}{*}{$n$} & \multicolumn{2}{|c|}{$\delta^{13} \mathrm{C}$} & \multicolumn{2}{|c|}{$\delta^{15} \mathrm{~N}$} & \multirow[b]{2}{*}{$n$} & \multicolumn{2}{|c|}{${ }^{87} \mathrm{Sr} /{ }^{86} \mathrm{Sr}$} \\
\hline & & Mean & $\mathrm{SD}$ & Mean & $\mathrm{SD}$ & & Mean & $\mathrm{SD}$ & Mean & SD & & Mean & SD \\
\hline Overall & 21 & -15.1 & 1.0 & 8.6 & 0.8 & 16 & -16.2 & 1.1 & 9.1 & 0.8 & 17 & 0.7085 & 0.0005 \\
\hline Females & 5 & -15.3 & 0.4 & 8.6 & 0.3 & 6 & -16.8 & 1.2 & 9.0 & 0.8 & 6 & 0.7082 & 0.0008 \\
\hline Males & 4 & -14.5 & 0.9 & 9.0 & 0.8 & 3 & -15.7 & 1.1 & 9.6 & 0.5 & 3 & 0.7085 & 0.0003 \\
\hline Subadults & 1 & -17.2 & 0.0 & 7.0 & 0.0 & 1 & -17.4 & 0.0 & 7.6 & 0.0 & 1 & 0.7080 & - \\
\hline Young Adults & 2 & -14.9 & 0.3 & 8.6 & 0.2 & 2 & -15.6 & 0.9 & 9.2 & 1.1 & 2 & 0.7088 & 0.0002 \\
\hline Middle Adults & 2 & -15.7 & 0.2 & 8.2 & 0.3 & 2 & -17.3 & 0.4 & 8.9 & 0.2 & 2 & 0.7075 & 0.0009 \\
\hline Old Adults & 3 & -14.4 & 0.8 & 9.2 & 0.8 & 1 & -16.6 & 0.0 & 9.0 & 0.0 & 2 & 0.7085 & 0.0002 \\
\hline
\end{tabular}

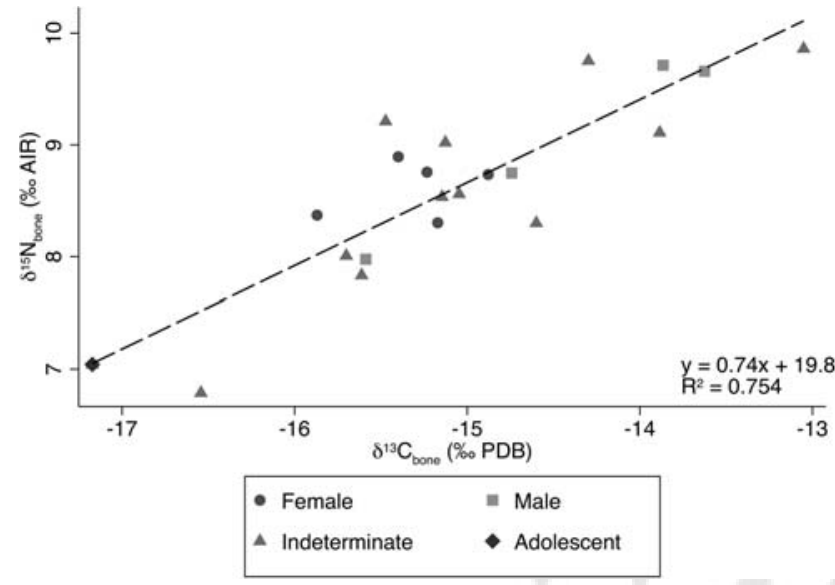

Fig. 4. $\delta^{13} \mathrm{C}_{\text {bone }}$ and $\delta^{15} \mathrm{~N}_{\text {bone }}$ results with fitted regression line.

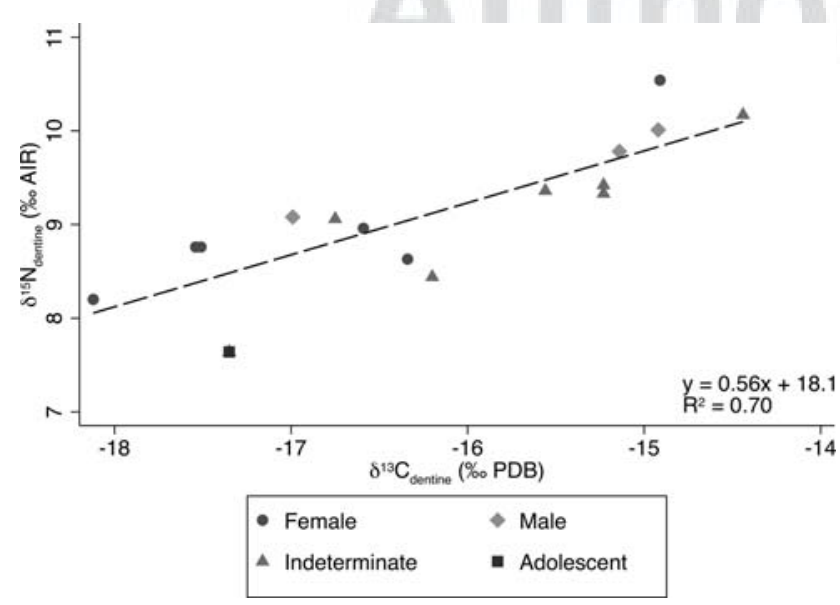

Fig. 5. $\delta^{13} \mathrm{C}_{\text {dentine }}$ and $\delta^{15} \mathrm{~N}_{\text {dentine }}$ results with fitted regression line.

analysis of enamel. While females displayed $\delta{ }^{13} \mathrm{C}_{\text {dentin }}$ values $1.1 \%$ lower than males on average, there were no significant differences between the sexes $(W(7)=15$, $z=-1.0, P=0.302)$. Females displayed $\delta{ }^{15} \mathrm{~N}_{\text {dentin }}$ values $0.6 \%$ lower than males on average, with no significant differences found, $(W(7)=15, z=-1.56, P=0.120)$.

Overall, ${ }^{87} \mathrm{Sr} /{ }^{86} \mathrm{Sr}$ ratios from tooth enamel of the Bourewa assemblage $(n=17)$ ranged between 0.7069 and 0.7089 (mean $=0.7085 \pm 0.0005)$. As displayed on

Figure 7, there is one individual outside two standard
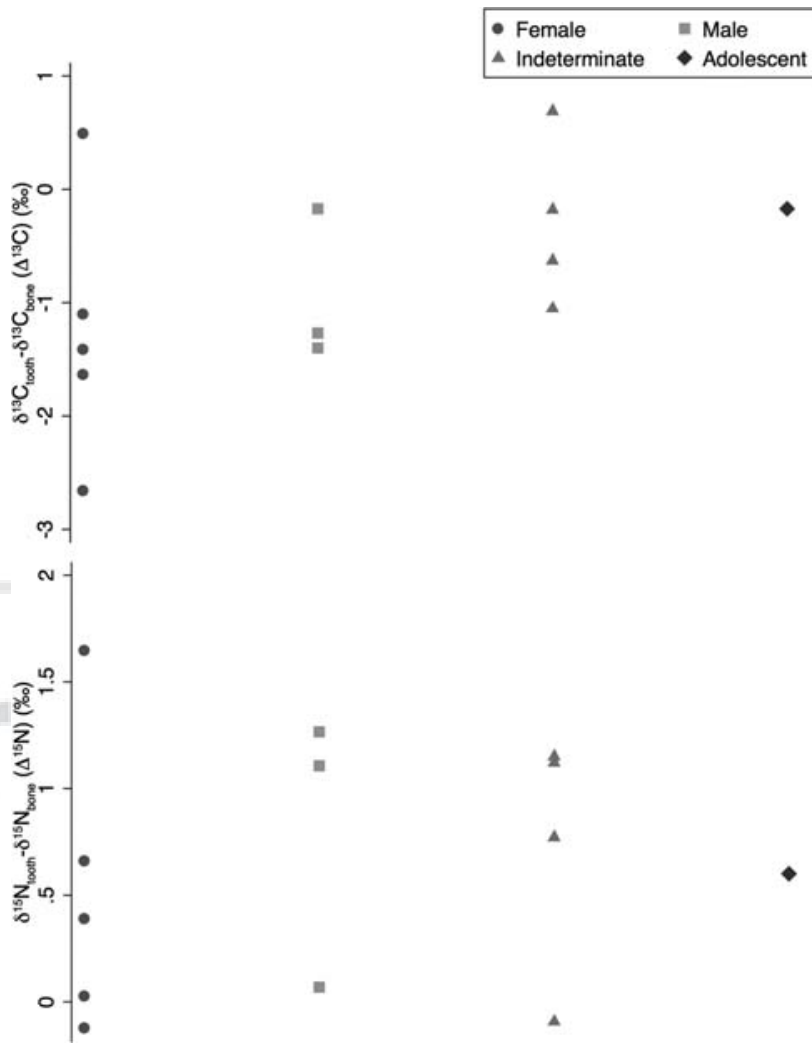

Fig. 6. $\delta^{13} \mathrm{C}_{\text {dentine }}-\delta^{13} \mathrm{C}_{\text {bone }}\left(\Delta^{13} \mathrm{C}\right)$ and $\delta^{15} \mathrm{~N}_{\text {dentine }}-\delta^{15} \mathrm{~N}_{\text {bone }}$ $\left(\Delta^{15} \mathrm{~N}\right)$ for the Bourewa assemblage. Negative $\Delta$ values indicate a higher bone collagen isotopic value than dentine collagen isotopic value within an individual, positive values indicate that the dentine collagen isotopic is higher than an individual's bone collagen isotopic value.

deviations from the ${ }^{87} \mathrm{Sr} /{ }^{86} \mathrm{Sr}$ mean, burial 23. With small cohort sizes when comparing the sexes (six females and three males), a Kruskal-Wallis test shows no significant differences between the sexes $(W(7)=15$, $z=-0.26, P=0.796$ ). Although the enamel and dentin do not necessarily record the exact time period of a person's life, dentin and enamel from the same tooth will form at roughly the same time and capture the same life period (e.g., roughly between the ages of five and ten years of age in the case of first and second molars and premolars). There were three individuals (burials 09, 23, and 31) that had different teeth sampled for the strontium analysis and for paleodietary isotope analysis and these individuals were excluded from these comparisons. 


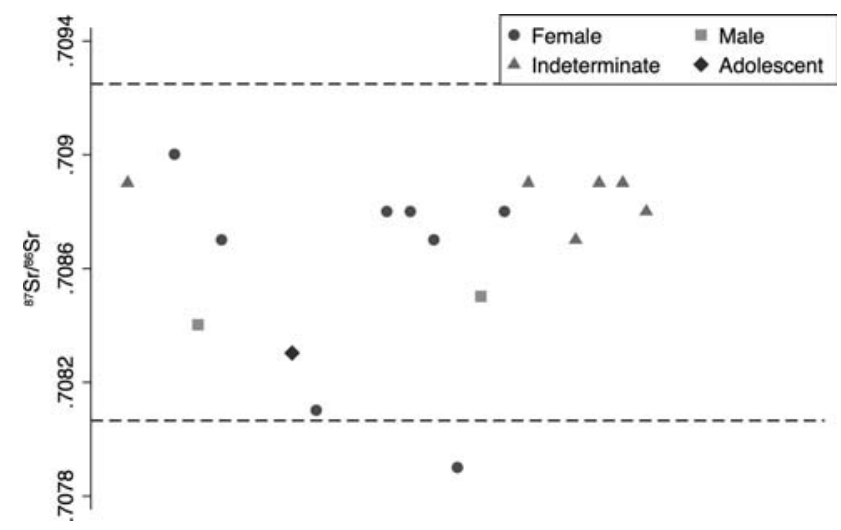

Fig. 7. ${ }^{87} \mathrm{Sr} /{ }^{86} \mathrm{Sr}$ results. Dashed lines delineate $2 \mathrm{SD}$ from the mean.

Pearson's correlations between ${ }^{87} \mathrm{Sr} /{ }^{86} \mathrm{Sr}$ ratios and dentin isotope values. There was a significant positive correlation between ${ }^{87} \mathrm{Sr} /{ }^{86} \mathrm{Sr}$ and $\delta^{13} \mathrm{C}_{\text {dentin }}, r(12)=0.63, P=$ 0.020 , but no significant correlation between ${ }^{87} \mathrm{Sr} /{ }^{86} \mathrm{Sr}$ ratios and $\delta^{15} \mathrm{~N}_{\text {dentin, }} r(12)=0.48 P=0.095$ (Fig. 8).

\section{DISCUSSION}

Figure 9 displays the $\delta^{13} \mathrm{C}_{\text {bone }}$ and $\delta^{15} \mathrm{~N}_{\text {bone }}$ values of the Bourewa assemblage, plotted against the tropical Pacific island dietary baseline (Kinaston et al., 2014a,b). The average $\delta^{13} \mathrm{C}$ bone and $\delta{ }^{15} \mathrm{~N}_{\text {bone values of the fruit }}$ bat plotted on Figure 9 represent an animal consuming an entirely terrestrial-based diet. The human values, when adjusted for trophic level enrichment, fall between the bone collagen values of the fruit bats and the lower trophic level marine foods (i.e., shellfish and seaweed). It is possible that $\mathrm{C}_{4}$ plants, most likely sugar cane in a Pacific island context, or sea grapes (Caulerpa racemosa) may have contributed to the diet. However, unless consumed in large amounts, these low-protein foods likely did not contribute substantially to the diet of the Bourewa individuals although further analyses of the $\delta^{13} \mathrm{C}$ values of bone carbonate would be necessary to confirm this (Froehle et al., 2012).

The significant correlation between the carbon and nitrogen values (for both bone and dentin) suggests that the main contributors of the protein portion of the Bourewa individuals' diets was derived principally from marine and terrestrial foods of different trophic levels (Richards and Hedges, 1999). If foods of the same trophic level or a single protein source were largely consumed, a strong positive correlation would not be present (Richards and Hedges, 1999; Kinaston et al., 2013a). A positive correlation has been observed in other prehistoric Pacific sites (Ambrose et al., 1997; Valentin et al., 2006; Kinaston et al., 2013a; Stantis et al., 2015) and fits with ethnohistoric accounts of Fijian diet, where farinaceous root vegetables and fruit trees were central to subsistence along with marine foods from the nearby reef and lagoon environment (Jones 2009). Mangrove shellfish, which display low $\delta^{15} \mathrm{~N}$ and $\delta^{13} \mathrm{C}$ values (Kinaston et al., 2014b), may also have been a contributor to dietary protein in the Bourewa diet.

Though the Bourewa assemblage is comparatively small, the assemblage provides an opportunity to compare adult and childhood diet in prehistoric Pacific island individuals who survived to adulthood. The $\Delta{ }^{13} \mathrm{C}$

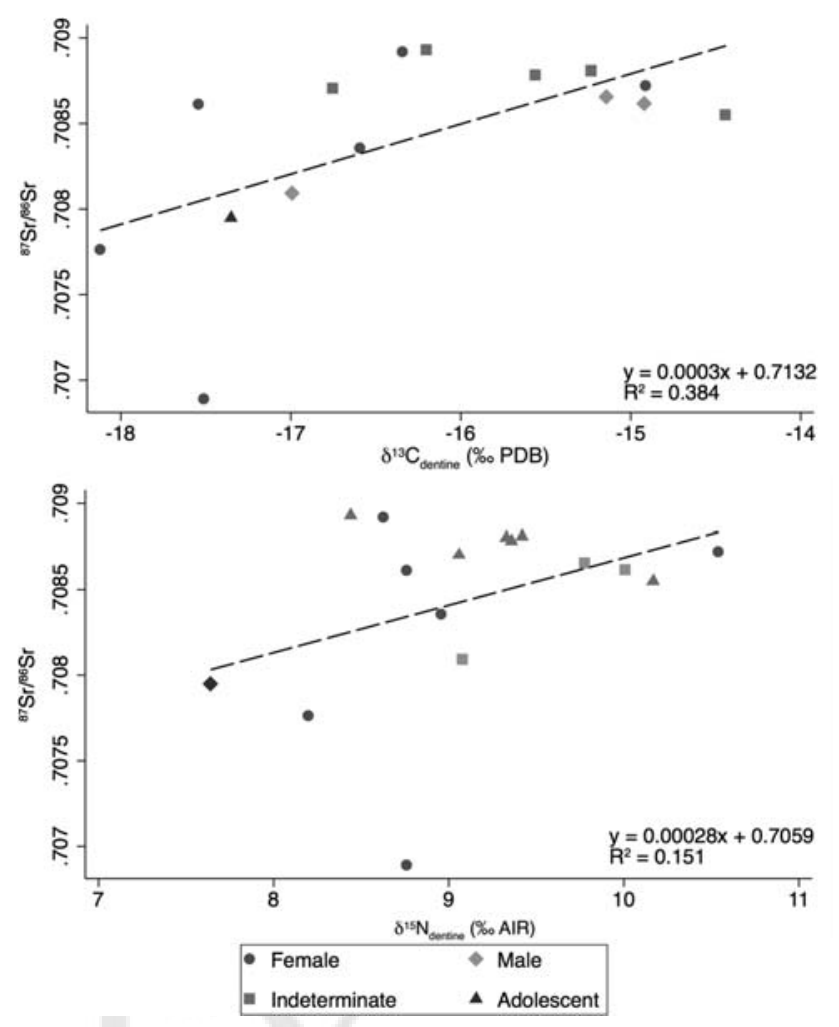

Fig. 8. ${ }^{87} \mathrm{Sr} /{ }^{86} \mathrm{Sr}$ and $\delta^{13} \mathrm{C}_{\text {dentine }}$ and ${ }^{87} \mathrm{Sr} /{ }^{86} \mathrm{Sr}$ and $\delta^{15} \mathrm{~N}_{\text {dentine }}$

value of the adolescent, Burial 15 , is very close to 0 at $0.2 \%$. This is expected given that the first molar (sampled for Burial 15) and bone values of an individual approximately 13 years of age would capture roughly the same time period due to possible bone turnover (Hedges et al., 2007). What is unexpected is that Burial 15 's $\Delta^{15} \mathrm{~N}$ value is near the assemblage mean at 0.6 , with several adults of indeterminate age displaying lower $\Delta^{15} \mathrm{~N}$ values.

The lower $\delta^{13} \mathrm{C}_{\text {dentin }}$ values compared with the $\delta^{13} \mathrm{C}_{\text {bone }}$ values suggest that the individuals from Bourewa consumed proportionately more terrestrial foods compared with marine foods in childhood compared with the last few years of their lives. A possible explanation is that the children were eating different foods compared with when they were adults. Significantly higher $\delta^{15} \mathrm{~N}_{\text {dentin }}$ values compared with adults eliminate fruits, such as bananas (Musa spp.) and coconuts (Cocos nucifera), as likely candidates for the isotopic differences. Canarium nuts would have been available seasonally in Fiji and could be preserved through smoking (Smith, 1979; Elevitch et al., 2006). Nuts display higher $\delta^{15} \mathrm{~N}$ values than other terrestrial plants while still displaying $\delta^{13} \mathrm{C}$ values within a terrestrial range (Kinaston et al., 2014a,b), and the consumption of nuts may therefore account for both the higher nitrogen and lower carbon values of the dentin. Modern Pacific children are also commonly seen snacking on lagoon and reef shellfish (Pollock, 1992; Jones, 2009), but this would raise $\delta^{13} \mathrm{C}_{\text {dentin }}$ rather than lower these values. The lower carbon and higher nitrogen values in childhood diets might not be a result of snacking, but a result of individuals being given (or withheld) certain types of foods at the communal meals depending on age. 


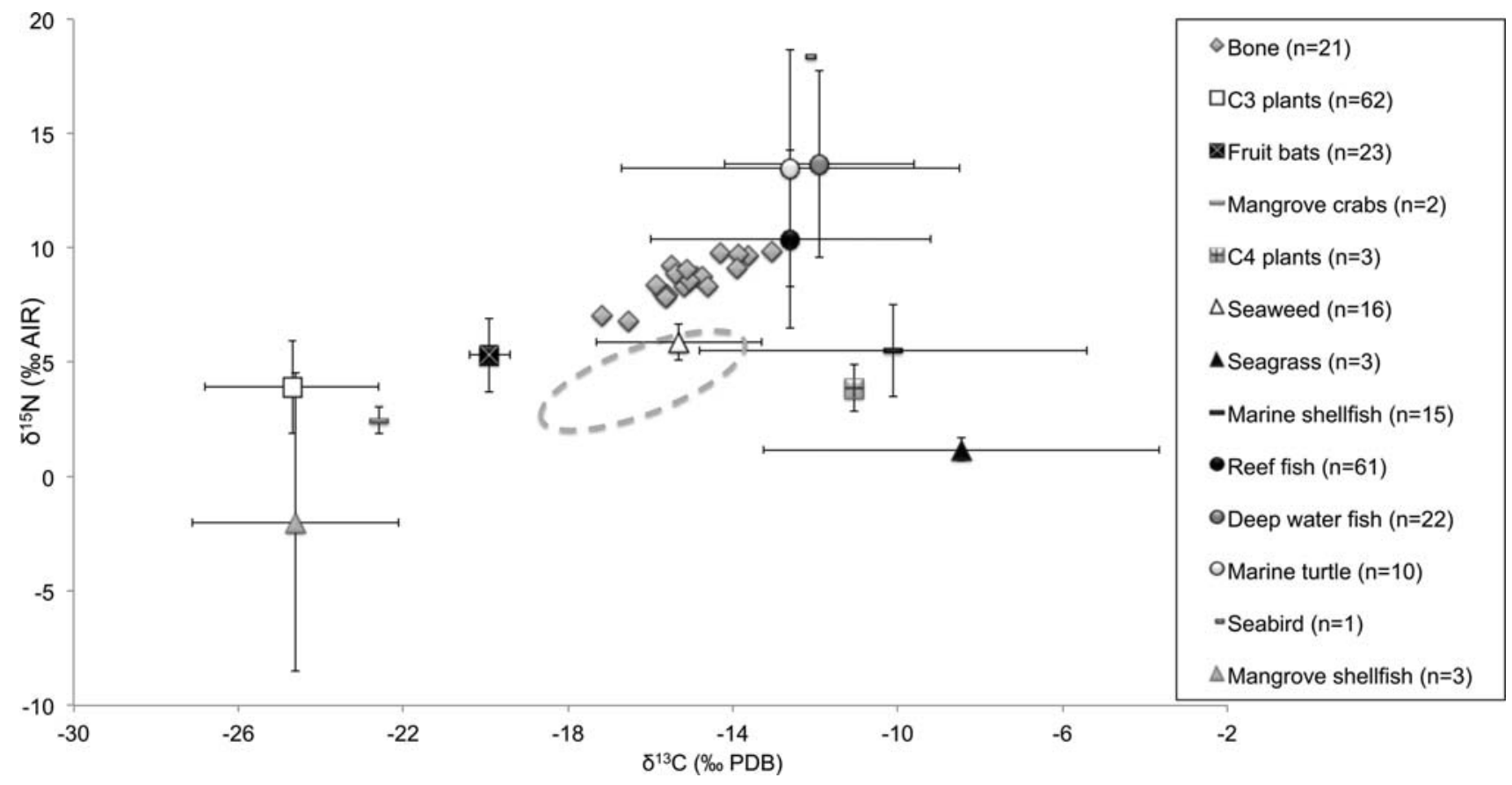

Fig. 9. The Bourewa $\delta^{13} \mathrm{C}_{\text {bone }}$ and $\delta^{15} \mathrm{~N}_{\text {bone }}$ results compared with dietary baseline data from previous studies (Kinaston et al., 2014a,b). Modern $\delta{ }^{13} \mathrm{C}$ values have been corrected for the Suess effect, but are otherwise unaltered. The dashed circle indicates the diet of the individuals once corrected for trophic level, $1 \%$ for $\delta^{13} \mathrm{C}$ and $4 \%$ for $\delta^{15} \mathrm{~N}$ values. [Color figure can be viewed in the online issue, which is available at wileyonlinelibrary.com.]

Physiological stress might also affect nitrogen values. Extreme nutritional stress such as starvation can also increase $\delta^{15} \mathrm{~N}$ values in mammals as the body may catabolize its own proteins when there is insufficient dietary protein (Hatch, 2012; Robertson et al., 2014; Beaumont et al., 2015). It is possible that the higher $\delta^{15} \mathrm{~N}$ values might not be a result of differences between childhood and adult diets, but that many of the Bourewa individuals were subjected to physiological stress at some point during their childhood. Low trophic level terrestrial foods combined with nutritional stress could explain the $\Delta^{13} \mathrm{C}$ and $\Delta^{15} \mathrm{~N}$ values. Investigating the pathological conditions within the skeletal assemblage may help in unraveling the potential interactions between childhood disease and diet in prehistoric Bourewa.

\section{Comparison of collagen isotopic values to other prehistoric pacific paleodietary studies}

When comparing the Bourewa stable isotope results to other paleodietary studies from Fiji and the nearby archipelagoes of Samoa, Tonga, and Vanuatu (Fig. 10), it becomes clear that there was considerable diversity in the dietary range of these Pacific Island groups. For example, the assemblages analyzed by Field et al. (2009) and Phaff (2012), though both are from the Sigatoka Valley on Viti Levu, display vastly different carbon stable isotope values. Despite being within the same geographic area, environmental differences between the two Sigatoka sites may be the underlying cause for the dietary variation. The individuals sampled by Phaff (2012) originated from the Sigatoka Sand Dunes near the mouth of the river and individuals analyzed by Field et al. (2009) were from inland settlements further upriver. Temporal variation is also a likely cause for much of the dietary variation between the samples from different Pacific island sites. For example, the individuals from the Teouma site on Efate island, Vanuatu (Kinaston et al., 2014b) and the late prehistoric/historic individuals from Uripiv Island, Vanuatu (Kinaston et al., 2014a), though only separated by a few hundred kilometers of ocean, a relatively short travel distance in the tropical Pacific, are separated by almost 3,000 years and display vastly different carbon and nitrogen isotope mean values (Kinaston et al., in press).

The Natunuku site on Viti Levu (c. 2000 BP) is the only Fijian site displaying higher carbon stable isotope values than the Bourewa sample, but it should be noted that there was only one individual available for analysis (Leach et al., 2003). Natunuku, like Bourewa and the Sigatoka Sand Dunes, is located on the coast. It is interesting that these coastal assemblages appear to be consuming a more marine diet compared with individuals from much smaller islands, like the assemblages from Cikobia Island (Valentin et al., 2006), Tongatapu (Stantis et al., 2015), and late prehistoric/historic individuals from Uripiv Island (Kinaston et al., 2014a), which are located on islands $19 \mathrm{~km}^{2}, 259 \mathrm{~km}^{2}$, and $<1 \mathrm{~km}^{2}$ in size, respectively. The small size of these islands could have presumably made horticultural subsistence less productive and necessitated a greater reliance on reef, deep water, and lagoon resources. Instead, these populations seem to have consumed proportionately more terrestrial resources. All three of these small island cohorts are dated to the late prehistoric/historic periods (there are individuals dated to earlier time periods on Uripiv, but only late prehistoric/historic individuals are discussed here). Thus, these individuals were living hundreds, if not thousands, of years after initial colonization of their respective archipelagoes and roughly contemporaneous 


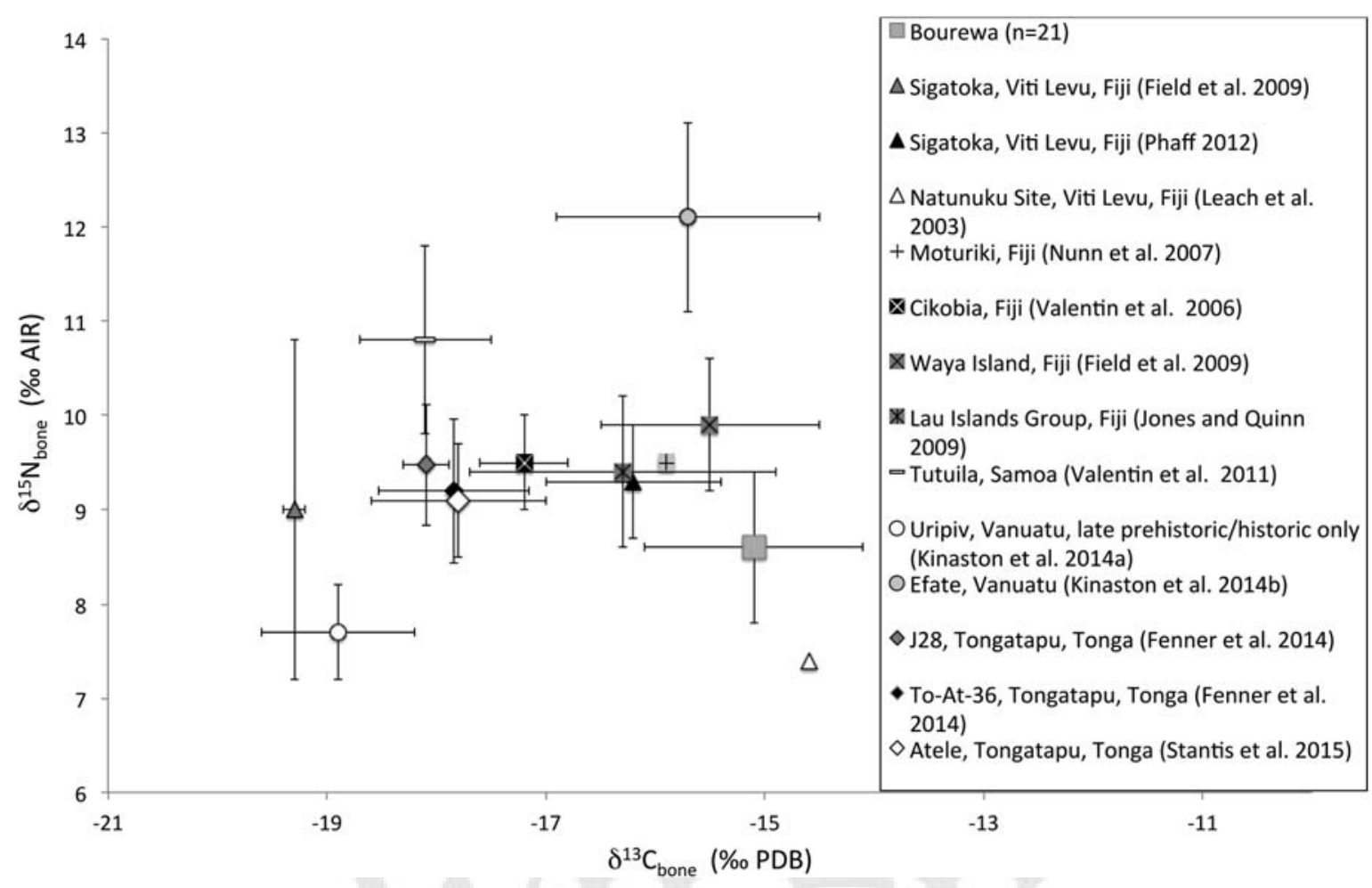

Fig. 10. Bourewa $\delta^{13} \mathrm{C}_{\text {bone }}$ and $\delta^{15} \mathrm{~N}_{\text {bone }}$ mean \pm 1 SD compared with mean $\pm 1 \mathrm{SD}$ of previous studies. [Color figure can be viewed in the online issue, which is available at wileyonlinelibrary.com.]

with Bourewa (Kinaston et al., 2014a; Stantis et al., 2015). That these late prehistoric/historic populations practiced intensive horticultural pursuits fits with the current archaeological models of later communities becoming less reliant on marine resources as their gardens become established and the local marine resources become rapidly depleted due to overuse by the initial settlers (Kirch and Hunt, 1997; Burley et al., 2001; Kennett et al., 2006; Kinaston et al., 2014b).

Why then did the Bourewa community rely so heavily on marine resources despite also being from late prehistory? One reason may be that there was no ecological pressure to discontinue heavy reliance on coastal resources. The source community (somewhere near Bourewa) may have been small enough, and/or the large fringing reef and lagoon on the coast of the Rove Peninsula may have been productive enough that marine resources provided one of the most important food resources at the site, and that garden foods were eaten in smaller proportions than at other sites in the Pacific Islands and Fiji.

The uncommon dryness and poor soils of the Rove Peninsula, on which Bourewa is located, may have also contributed to the emphasis on marine food consumption, a similar situation for subsistence communities in the area today (Nunn, 2009). Trade with other, more inland, communities may have been restricted because of conflict and the increased competition for resources during this period, further restricting opportunities to secure horticultural foods (Field, 2004, 2005; Nunn, 2012).

The heavy reliance on marine foods with terrestrial garden plants providing a lesser dietary contribution is not the typical subsistence pattern observed in the tropical Pacific, where normally the farinaceous root crops are the basis of subsistence and are supplemented by marine protein (Pollock, 1992; Jones, 2009; Kirch, 2000). The examination of dietary isotopes from collagen generally reveals information about the protein portion of an individual's diet (Ambrose and Norr, 1993; Fernandes et al., 2012). As such, low protein foods (such as terrestrial plants) could be overshadowed by higher-protein sources such as marine animals (Hedges, 2004). As other prehistoric tropical Pacific cultures largely consumed the same types of foods $\left(\mathrm{C}_{3}\right.$ plants and marine resources, albeit in different proportions) (Kirch, 2000), the comparison of the isotope results to previous prehistoric Pacific paleodietary studies aids in understanding the types of food consumed and the relative proportion of marine foods compared with terrestrial foods in Bourewa individuals, which appears to be much more than the other Pacific island samples analyzed previously.

Without individuals from earlier time periods from the Rove Peninsula to analyze, it is not possible to determine whether the higher proportion of marine foods in the Bourewa diet was an adaptation to the devastation of terrestrial resources during the Vuda Phase (Kumar et al., 2006; Nunn, 2012a,b) or an indication of a lack of ecological pressure to intensify horticultural subsistence. A thorough examination of skeletal indicators of nonspecific and nutritional stress in this assemblage, as has been conducted in other prehistoric tropical Pacific communities (Buckley, 2000; Buckley et al., 2014), are underway and will be useful to help further understand the biocultural pressures affecting this population.

Unfortunately, there are few studies of prehistoric Pacific islanders utilizing stable isotope analyses of dentin to assess paleodiet. Human teeth from a Marquesas Islands site in French Polynesia (Richards et al., 2009) 
provide the only paleodietary analyses of dentin in the prehistoric Pacific. The four teeth from the Marquesas display much higher mean $\delta^{15} \mathrm{~N}_{\text {dentin }}$ than the other assemblages, 18.8 \pm 1.7 . Richards et al. (2009) posit that a diet high in terrestrial animals (pigs, dogs, and rats) is the cause of these high nitrogen values. One possible contribution to these high values may have been the breastfeeding effect: of the four teeth sampled by Richards et al. (2009), one was a deciduous second molar and one was a permanent canine. These teeth begin dentin formation in utero and within 3 to 4 months of age, respectively, and breastfeeding signals may be the cause of these individual's higher trophic level compared with the individuals from this study.

\section{Mobility in Bourewa and the relationship between ${ }^{87} \mathrm{Sr} /{ }^{86} \mathrm{Sr}$ and dietary isotopes}

In the Bourewa assemblage, there was a significant positive relationship between ${ }^{87} \mathrm{Sr} /{ }^{86} \mathrm{Sr}$ ratios and $\delta^{13} \mathrm{C}_{\text {dentin }}$ values, though no significant correlation between ${ }^{87} \mathrm{Sr} /{ }^{86} \mathrm{Sr}$ ratios and $\delta^{15} \mathrm{~N}_{\text {dentin }}$ values was observed. With lower ${ }^{87} \mathrm{Sr} /{ }^{86} \mathrm{Sr}$ ratios suggestive of childhood residence inland in the Pacific, and lower $\delta^{13} \mathrm{C}_{\text {dentin }}$ indicative of more terrestrial-based diets, the positive correlation between these values makes sense given the context.

Most of the individuals interred in Bourewa display ${ }^{87} \mathrm{Sr} /{ }^{86} \mathrm{Sr}$ ratios similar to the value of modern seawater (0.7092). Given the coastal location of the site and the partially limestone bedrock, high ${ }^{87} \mathrm{Sr} /{ }^{86} \mathrm{Sr}$ are expected as a marine-based diet and the consumption of terrestrial foods grown in soil exposed to seaspray/marinederived precipitation will yield ${ }^{87} \mathrm{Sr} /{ }^{86} \mathrm{Sr}$ ratios similar to seawater (Whipkey et al., 2000). The ${ }^{87} \mathrm{Sr} /{ }^{86} \mathrm{Sr}$ ratio of the individual from burial 23 is outside the average of the site by two standard deviations, and is the lowest ratio in the assemblage. Given the comparatively high ${ }^{87} \mathrm{Sr} /{ }^{86} \mathrm{Sr}$ ratio of seawater and low ${ }^{87} \mathrm{Sr} /{ }^{86} \mathrm{Sr}$ ratios of the underlying geology on inland Fiji, Burial 23 may have spent her childhood inland rather than on the coast. Burial 23 had a childhood diet which was amongst the most terrestrial in the sample, as indicated by her low $\delta^{13} \mathrm{C}_{\text {dentin }}$ values. This conclusion is consistent with modern life in rural Fiji where women generally move to their husband's village after marriage (Nayacakalou 1955; Becker, 1995; Jones, 2009); it is plausible to suppose that burial 23 was a woman raised in the interior who did in fact marry a coastal man.

Other individuals may have spent their childhood in locations outside Bourewa, but if these locations were also coastal or small coralline islands then there is no means of differentiating them from the locals using only ${ }^{87} \mathrm{Sr} /{ }^{86} \mathrm{Sr}$ analysis with two standard deviations from the mean as the method of classifying nonlocals. Beyond burial 23 , two other individuals display low ${ }^{87} \mathrm{Sr} /{ }^{86} \mathrm{Sr}$ ratios (though within two standard deviations of the mean). The other individuals with the lowest ${ }^{87} \mathrm{Sr} /{ }^{86} \mathrm{Sr}$ ratios are burial 17, a female of unknown age, and burial 15, the only subadult in the assemblage. Along with burial 23, these two individuals display the three lowest $\delta^{13} \mathrm{C}_{\text {dentin }}$ values within the assemblage, consuming proportionately more terrestrial foods than the rest. It is possible these two individuals spent their childhood elsewhere consuming a different diet from the Bourewa locals, but in an area that has a similar underlying geology to the childhood residence of the rest of the sample.
The establishment of bioavailable strontium baseline in southwestern Viti Levu may more definitively identify locals and nonlocals in the area. Until then, the use of childhood diet can serve as another approach for investigating migration and childhood residence.

The presence of other individuals with low ${ }^{87} \mathrm{Sr} /{ }^{86} \mathrm{Sr}$ ratios and the potential of other nonlocals with strontium compositions reflective of sea-water (either from living in limestone areas, eating from foodwebs affected by seaspray/marine-derived precipitation, or consuming marine foods) highlights the need for more exacting means of determining prehistoric mobility in the tropical Pacific. The analysis of other isotopes and trace element ratios has enabled Pacific archaeologists to determine nonlocals in populations who would not necessarily have been detected with only ${ }^{87} \mathrm{Sr} /{ }^{86} \mathrm{Sr}$ analysis (Bentley et al., 2007; Shaw et al., 2010, 2011). The use of a bioavailable strontium baseline has also yielded more accurate means of understanding mobility in Vanuatu (Kinaston et al., 2014a). The incorporation of either of these approaches in future research would likely confirm if burials 15 and 17 are possibly nonlocals and would help identify other nonlocals, if present.

Though future analyses of paleomobility using other lines of evidence in Bourewa may reveal other nonlocals, with only one nonlocal as determined by strontium analysis, it is impossible to address our hypothesis regarding patrilocality.

\section{Sex-based differences}

Though a comparatively small sample size, there were no significant differences in ${ }^{87} \mathrm{Sr} /{ }^{86} \mathrm{Sr}$ ratios. Though the only nonlocal identified using the 2SD cut-off is female and one of the other two potential nonlocals identified using childhood diet is also female, any supposition regarding patrilocality cannot be supported or disproven given the small sample size. The lack of sex-based differences regarding locality is similar to the past mobility studies in the Pacific islands which find no clear trend towards one sex being more mobile than the other (Bentley et al., 2007; Shaw et al., 2009, 2010, 2011; Kinaston et al., 2014a).

There were also no differences between the sexes regarding carbon and nitrogen values in bone and dentin collagen. It should be noted that there were also no sexbased differences in diet found through isotopic analyses of bone on Cikobia, a smaller Fijian island northeast of Viti Levu (Valentin et al., 2006), leaving the possibility that it is not so unusual for equal access to certain types of food in Fiji. The Cikobia assemblage is late prehistoric/historic (c. $100 \mathrm{BP}$ ) and also suffers from a small comparative sample for sex comparisons (five males and two females).

The lack of sex-based differences in Bourewa could simply be a sampling issue, and the nine individuals of estimated sex with cortical bone for isotopic analyses might not be entirely representative the living population from which they were derived (Wood et al., 1992; Waldron, 1994). With the assumption that this pattern is representative of the living population's diet, then perhaps there were mitigating factors reducing the typical dietary differences between the sexes observed in other prehistoric Pacific samples. If the Bourewa diet, as observed through isotopic analyses, was an adaptation to the devastation of terrestrial resources during the Vuda Phase or an indication of the lack of ecological 
pressure to intensify horticultural pursuits, as discussed above, it is possible that the resource pressures reduced individual choice, lifted food taboos (if present), or encouraged food-sharing. In direct conflict with this supposition, there is strong evidence in modern events of food insecurity that certain household members, most often males as the primary resource providers, are given priority for food (Wutich and Brewis, 2014). Nonetheless, Wutich and Brewis (2014) concede that there are few archaeological, ethnographic, and historical pointers to this conclusion. Regardless, without more isotopic data from individuals of estimated sex from other time periods (and an increased sample size from the Vuda Phase) it is difficult to determine whether climatic pressures had an influence on resource allocation at the site, and if these would be visible isotopically.

\section{CONCLUSION}

The paleodietary isotopes discussed in this study suggest that the Bourewa individuals relied heavily on marine organisms from lower trophic levels, such as those from inshore and reef environments. Terrestrial plants and/or mangrove shellfish are also likely contributors to their adult diet in a lesser proportion. Lower $\delta^{13} \mathrm{C}_{\text {dentin }}$ values relative to $\delta^{13} \mathrm{C}_{\text {bone }}$ values implies that childhood diet may have included proportionately more terrestrial plants/mangrove shellfish compared with the adult diets. In comparison to other prehistoric Pacific populations, Bourewa individuals relied more heavily on marine foods. Significant dietary differences between adults and childhood diets supported the second hypothesis of this study, though the lack of dietary differences between the sexes did not. $\Delta^{13} \mathrm{C}$ values in this assemblage tended to be negative while $\Delta^{15} \mathrm{~N}$ values were, on average, positive. Whether or not these $\Delta$ values are a result of diet, stress, or some other physiological phenomenon is unknown. A more thorough investigation of $\Delta^{13} \mathrm{C}$ and $\Delta^{15} \mathrm{~N}$ in archaeologically-derived individuals and examination of this phenomenon, if it is in fact a pattern, in a controlled setting will be necessary to determine the extent and potential causes.

One individual was found with a low ${ }^{87} \mathrm{Sr} /{ }^{86} \mathrm{Sr}$ ratio that was outside two standard deviations of the average of all measurements, and so likely spent her childhood in a location other than Bourewa, perhaps inland from the coast. Burial 23's childhood diet, as inferred from isotopic analysis of dentin collagen, is among the more terrestrially-derived diets in the assemblage but is not outside the population mean. Other individuals, an adult female of indeterminate age (Burial 17) and an adolescent (Burial 15) also display low ${ }^{87} \mathrm{Sr} /{ }^{86} \mathrm{Sr}$ ratios and diets relying more on terrestrial foods and may have spent their childhood elsewhere. The relatively small number of individuals who could be identified as migrants is in conflict with our initial expectations, though we acknowledge that the use of other isotopic indicators of movement (i.e., lead and oxygen isotope analyses) could help to identify other nonlocals within the population, as would the collection of bioavailable ${ }^{87} \mathrm{Sr} /{ }^{86} \mathrm{Sr}$ ratios for the study region. Though the only ${ }^{87} \mathrm{Sr} /{ }^{86} \mathrm{Sr}$ outlier (Burial 23) is female, with only one point of data our hypothesis regarding a greater proportion of nonlocal females cannot be accepted or rejected.

Our study illustrates the challenges of using isotopic analyses to understand diet and mobility in Fiji. With so few comparative Fiji populations of substantial size, it is difficult to determine whether the marine-focused diet of the Bourewan individuals is typical within the archipelago. The bountiful fringing reef near the site could have reduced the necessity for intensive horticultural practices, which the local environment did not encourage. Similarly, we cannot determine whether or not the lack of sex-based differences was a response to resource pressures during ENSO events without more information about the diet of Vuda Phase individuals from across Viti Levu. Expanding the use of a multi-isotopic approach in other sites will be essential to understanding the interactions between Fijian societies and climate change.

\section{ACKNOWLEDGEMENTS}

The authors thank Lysann Rädisch and Sven Steinbrenner at the Max Planck Institute for their technical advice. The authors are especially grateful to Dr. Fiona Petchey (University of Waikato), who was invaluable in her help regarding radiocarbon dating. The suggestions of the two anonymous reviewers strengthened this manuscript and we thank them for their time.

\section{LITERATURE CITED}

Allen MS, Craig JA. 2009. Dynamics of Polynesian subsistence: insights from archaeofauna and stable isotope studies, Aitutaki, Southern Cook Islands. Pacific Sci 63:477-506.

Ambrose SH. 1990. Preparation and characterization of bone and tooth collagen for isotopic analysis. J Archaeol Sci 17: 431-451.

Ambrose SH. 1993. Isotopic analysis of paleodiets: methodological and interpretive considerations. In: Sandford MK, editor. Investigations of ancient human tissue: chemical analysis in anthropology. Philidelphia, PA: Gordon and Breach. p 59-130.

Ambrose SH, Butler BM, Hanson DB, Hunter-Anderson RL, Krueger HW. 1997. Stable isotopic analysis of human diet in the Marianas Archipelago, Western Pacific. Am J Phys Anthropol 104:343-361.

Ambrose SH, Krigbaum J. 2003. Bone chemistry and bioarchaeology. J Anthropol Archaeol 22:193-199.

Ambrose SH, Norr L. 1992. On stable isotopic data and prehistoric subsistence in the Soconusco region. Curr Anthropol 33: 401-404.

Ambrose SH, Norr L. 1993. Experimental evidence for the relationship of the carbon isotope ratios of whole diet and dietary protein to those of bone collagen and carbonate. In: Lambert JB, Grupe G, editors. Prehistoric human bone. Springer Berlin Heidelberg. p 1-37.

Anderson A. 2002. Faunal collapse, landscape change and settlement history in remote Oceania. World Archaeol 33:375390 .

Anderson A, Roberts R, Dickinson W, Clark G, Burley D, de Biran A, Hope G, Nunn P. 2006. Times of sand: Sedimentary history and archaeology at the Sigatoka Dunes, Fiji. Geoarchaeology 21:131-154.

Barrau J. 1961. Subsistence agriculture in Polynesia and Micronesia. Honolulu, Hawaii: Bernice P. Bishop Museum.

Barry H, Paxson LM. 1971. Infancy and early childhood: crosscultural codes 2. Ethnology 10:466-508.

Beaumont J, Gledhill A, Lee-Thorp J, Montgomery J. 2013. Childhood diet: a closer examination of the evidence from dental tissues using stable isotope analysis of incremental human dentine. Archaeometry 55:277-295.

Beaumont J, Montgomery J, Buckberry J, Jay M. 2015. Infant mortality and isotopic complexity: new approaches to stress, maternal health, and weaning. Am J Phys Anthropol 157: 441-457.

Becker AE. 1995. Body, self, and society: the view from Fiji. Philadelphia: University of Pennsylvania Press. 
Bentley RA. 2006. Strontium isotopes from the earth to the archaeological skeleton: a review. J Archaeol Method Theor 13:135-187.

Bentley RA, Buckley HR, Spriggs M, Bedford S, Ottley CJ, Nowell GM, Macpherson CG, Pearson DG. 2007. Lapita migrants in the Pacific's oldest cemetery: isotopic analysis at Teouma, Vanuatu. Am Antiquity 72:645-656.

Bentley RA, Knipper C. 2005. Geographical patterns in biologically available strontium, carbon, and oxygen isotope signatures in prehistoric SW Germany. Archaeometry 47:629-644.

Best S. 1984. Lakeba: the prehistory of a Fijian Island. Auckland, NZ: University of Auckland.

Bocherens H, Drucker D. 2003. Trophic level isotopic enrichment of carbon and nitrogen in bone collagen: case studies from recent and ancient terrestrial ecosystems. Int J Osteoarchaeol 13:46-53.

Bromfield K, Renema W. 2011. Comparison of ${ }^{87} \mathrm{Sr} /{ }^{86} \mathrm{Sr}$ isotope and biostratigraphic ages of uplifted fossil reefs in the IndoPacific: Indonesia, Papua New Guinea and Fiji. Aust J Earth Sci 58:61-73.

Brown TA, Nelson DE, Vogel JS, Southon JR. 1988. Improved collagen extraction by modified Longin method. Radiocarbon 30:171-177.

Buckley HR. 2000. Subadult health and disease in prehistoric Tonga, Polynesia. Am J Phys Anthropol 113:481-505.

Buckley HR, Kinaston R, Halcrow SE, Foster A, Spriggs M, Bedford S. 2014. Scurvy in a tropical paradise? Evaluating the possibility of infant and adult vitamin $\mathrm{C}$ deficiency in the Lapita skeletal sample of Teouma, Vanuatu, Pacific islands. Int J Paleopathol 5:72-85.

Buikstra JE, Ubelaker DH. 1994. Standards for data collection from human skeletal remains. Fayetteville: Arkansas Archaeological Survey.

Burley D, Clark JT. 2003. The archaeology of Fiji/Western polynesian in the post-Lapita era. In: Sand C, editor. Pacific archaeology: assessments and prospects. Proceedings of the International Conference for the 50th Anniversary of the First Lapita Excavation, Koné-Nouméa. New Caledonia: Département Archéologie, Service des Musées et du Patrimoine de Nouvelle-Calédonie. p 221-235.

Burley DV. 2003. Dynamic landscapes and episodic occupations: archaeological interpretation and implications in the prehistory of the Sigatoka Sand Dunes. In: Sand C, editor. Pacific archaeology: assessments and prospects. Noumeá, New Caledonia: Le Cahiers de l'Archeologie en Nouvelle Caledonie. p 307-315.

Burley DV, Dickinson WR, Barton A, Shutler R. 2001. Lapita on the periphery. New data on old problems in the Kingdom of Tonga. Archaeol Oceania 36:89-104.

Burton J. 2008. Bone chemistry and trace element analysis. In: Katzenberg MA, Saunders SR, editors. Biological anthropology of the human skeleton. Chichester, UK: Wiley. p 443-460.

Burton JH, Price TD. 1999. Evaluation of bone strontium as a measure of seafood consumption. Int J Osteoarchaeol 9:233236.

Chiaradia M, Gallay A, Todt W. 2003. Different contamination styles of prehistoric human teeth at a Swiss necropolis (Sion, Valais) inferred from lead and strontium isotopes. Appl Geochem 18:353-370.

Clark G, Anderson A. 2009. Colonisation and culture change in the early prehistory of Fiji. In: Clark G, Anderson A, editors. The early prehistory of Fiji. Canberra: ANU Press. p 407-437.

Collins MJ, Galley P. 1998. Towards an optimal method of archaeological collagen extraction: the influence of $\mathrm{pH}$ and grinding. Ancient Biomol 2:209-222.

Deniel C, Pin C. 2001. Single-stage method for the simultaneous isolation of lead and strontium from silicate samples for isotopic measurements. Anal Chim Acta 426:95-103.

DeNiro MJ. 1985. Postmortem preservation and alteration of in vivo bone collagen isotope ratios in relation to palaeodietary reconstruction. Nature 317:806-809.

DeNiro MJ, Epstein S. 1978a. Carbon isotopic evidence for different feeding patterns in two hyrax species occupying the same habitat. Science 201:906-908.
DeNiro MJ, Epstein S. 1978b. Influence of diet on the distribution of carbon isotopes in animals. Geochim Cosmochim Acta 42:495-506.

Elderfield H. 1986. Strontium isotope stratigraphy. Palaeogeogr Palaeoclimatol Palaeoecol 57:71-90.

Elevitch CR, Abbott IA, Leakey RRB. 2006. Traditional trees of Pacific Islands: their culture, environment, and use. Hōlualoa, Hawaii: Permanent Agriculture Resources.

Evans JA, Montgomery J, Wildman G. 2009. Isotope domain mapping of ${ }^{87} \mathrm{Sr} /{ }^{86} \mathrm{Sr}$ biosphere variation on the Isle of Skye, Scotland. J Geol Soc 166:617-631.

Evans JA, Montgomery J, Wildman G, Boulton N. 2010. Spatial variations in biosphere $87 \mathrm{Sr} / 86 \mathrm{Sr}$ in Britain. J Geol Soc 167: $1-4$.

Faure G, Powell JL. 1972. Strontium isotope geology. Berlin, Germany: Spring-Verlag.

Fenner JN, Clark G, Cressey A, Valentin F, Olesen SH, Armstrong R. 2015. Isotopic uniformity and segregation in Tongan mounds. J Archaeol Sci Rep 2:644-653.

Fernandes R, Nadeau M-J, Grootes P. 2012. Macronutrientbased model for dietary carbon routing in bone collagen and bioapatite. Archaeol Anthropol Sci 4:291-301.

Field JS. 2004. Environmental and climatic considerations: a hypothesis for conflict and the emergence of social complexity in Fijian prehistory. J Anthropol Archaeol 23:79-99.

Field JS. 2005. Land tenure, competition and ecology in Fijian prehistory. Antiquity 79:586-600.

Field JS, Cochrane EE, Greenlee DM. 2009. Dietary change in Fijian prehistory: isotopic analyses of human and animal skeletal material. J Archaeol Sci 36:1547-1556.

Field JS, Lape PV. 2010. Paleoclimates and the emergence of fortifications in the tropical Pacific islands. J Anthropol Archaeol 29:113-124.

Froehle AW, Kellner CM, Schoeninger MJ. 2010. FOCUS: effect of diet and protein source on carbon stable isotope ratios in collagen: follow up to Warinner and Tuross (2009). J Archaeol Sci 37:2662-2670.

Froehle AW, Kellner CM, Schoeninger MJ. 2012. Multivariate carbon and nitrogen stable isotope model for the reconstruction of prehistoric human diet. Am J Phys Anthropol 147: 352-369.

Frost EL. 1979. Fiji. The prehistory of Polynesia. Australian National University Press. p 61-81.

Fry B, Lutes R, Northam M, Parker PL, Ogden J. 1982. A ${ }^{13} \mathrm{C} /{ }^{12} \mathrm{C}$ comparison of food webs in Caribbean seagrass meadows and coral reefs. Aquatic Bot 14:389-398.

Fuller BT, Richards MP, Mays SA. 2003. Stable carbon and nitrogen isotope variations in tooth dentine serial sections from Wharram Percy. J Archaeol Sci 30:1673-1684.

Gill JB. 1984. Sr-Pb-Nd isotopic evidence that both MORB and OIB sources contribute to Oceanic island arc magmas in Fiji. Earth Planet Sci Lett 68:443-458.

Green RC. 1963. A suggested revision of the Fijian sequence. J Polynesian Soc 72:235-253.

Hatch K. 2012. The use and application of stable isotope analysis to the study of starvation, fasting, and nutritional stress in animals. In: Comparative physiology of fasting, starvation, and food limitation. Springer-Berlin Heidelberg. p 337-364.

Hedges REM. 2004. Isotopes and red herrings: comments on Milner et al., and Lidén et al., Antiquity 78:34-37.

Hedges REM, Clement JG, Thomas CDL, O'Connell TC. 2007. Collagen turnover in the adult femoral mid-shaft: Modeled from anthropogenic radiocarbon tracer measurements. Am J Phys Anthropol 133:808-816.

Hillson S. 1996. Dental anthropology. Cambridge: Cambridge University Press.

Hoefs J. 2009. Stable isotope geochemistry. Berlin: SpringerVerlag.

Horrocks M, Nunn PD. 2007. Evidence for introduced taro (Colocasia esculenta) and lesser yam (Dioscorea esculenta) in Lapita-era (c. 3050-2500 BP) deposits from Bourewa, southwest Viti Levu Island, Fiji. J Archaeol Sci 34:739-748.

Huebert JM, Allen MS, Wallace RT. 2010. Polynesian earth ovens and their fuels: wood charcoal remains from Anaho 
Valley, Nuku Hiva, Marquesas Islands. J Polynesian Soc 119: 61-97.

Johnson CM, Lipman PW, Czamanske GK. 1990. H, O, Sr, Nd, and $\mathrm{Pb}$ isotope geochemistry of the Latir volcanic field and cogenetic intrusions, New Mexico, and relations between evolution of a continental magmatic center and modifications of the lithosphere. Contribut Mineral Petrol 104:99-124.

Jones S. 2009. Food and gender in Fiji: ethnoarchaeological explorations. Lanham, MD: Lexington Books.

Jones S, Quinn RL. 2009. Prehistoric Fijian diet and subsistence: integration of faunal, ethnographic, and stable isotopic evidence from the Lau Island Group. J Archaeol Sci 36:27422754.

Jones S, Walsh-Haney H, Quinn R. 2015. Kana Tamata or feasts of men: an interdisciplinary approach for identifying Cannibalism in Prehistoric Fiji. Int J Osteoarchaeol 25:127145.

Katzenberg MA. 2007. Stable isotope analysis: a tool for studying past diet, demography, and life history. Biological anthropology of the human skeleton. Wiley. p 411-441.

Katzenberg MA, Herring DA, Saunders SR. 1996. Weaning and infant mortality: evaluating the skeletal evidence. Am J Phys Anthropol 101:177-199.

Katzenberg MA, Lovell NC. 1999. Stable isotope variation in pathological bone. Int J Osteoarchaeol 9:316-324.

Katzenberg MA, Weber A. 1999. Stable isotope ecology and palaeodiet in the Lake Baikal Region of Siberia. J Archaeol Sci 26:651-659.

Keegan WF, DeNiro MJ. 1988. Stable carbon- and nitrogenisotope ratios of bone collagen used to study coral-reef and terrestrial components of prehistoric Bahamian diet. Am Antiquity 53:320-336.

Kellner CM, Schoeninger MJ. 2007. A simple carbon isotope model for reconstructing prehistoric human diet. Am J Phys Anthropol 133:1112-1127.

Kennett D, Anderson A, Winterhalder B. 2006. The ideal free distribution, food production, and the colonization of Oceania. In: Kennett D, Winterhalder B, editors. Behavioral ecology and the transition to agriculture. Berkley, CA: University of California Press.

Kinaston R, Bedford S, Richards M, Hawkins S, Gray A, Jaouen K, Valentin F, Buckley H. 2014a. Diet and human mobility from the lapita to the early historic period on Uripiv Island, Northeast Malakula, Vanuatu. PLoS One 9:e104071.

Kinaston R, Buckley H, Valentin F, Bedford S, Spriggs M, Hawkins S, Herrscher E. 2014b. Lapita diet in remote Oceania: new stable isotope evidence from the 3000-year-old Teouma site, Efate Island, Vanuatu. PLoS One 9:e90376.

Kinaston RL, Anson D, Petchey P, Walter R, Robb K, Buckley H. 2015. Lapita diet and subsistence strategies on Watom Island, Papua New Guinea: new stable isotope evidence from humans and animals. Am J Phys Anthropol 157:30-41.

Kinaston RL, Bedford S, Spriggs M, Buckley HR. In press. Is there a 'Lapita diet'? A comparison of Lapita and post-Lapita skeletal samples from four Pacific island archaeological sites. In: Oxenham MF, Buckley HR, editors. The Routledge handbook of bioarchaeology in Southeast Asia and the Pacific. London, UK: Routledge.

Kinaston RL, Buckley HR, Gray A. 2013a. Diet and social status on Taumako, a Polynesian outlier in the Southeastern Solomon Islands. Am J Phys Anthropol 151:589-603.

Kinaston RL, Walter RK, Jacomb C, Brooks E, Tayles N, Halcrow SE, Stirling C, Reid M, Gray AR, Spinks J, et al. 2013b. The first New Zealanders: patterns of diet and mobility revealed through isotope analysis. Plos One 8:e64580.

Kirch PV. 2000. On the road of the winds: an archaeological history of the Pacific Islands before European contact. Berkeley and Los Angeles: University of California Press.

Kirch PV, Hunt TL. 1997. Historical ecology in the Pacific Islands: prehistoric environmental and landscape change. New Haven: Yale University Press.

Krueger HW, Sullivan CH. 1984. Models for carbon isotope fractionation between diet and bone. Stable isotopes in nutrition. American Chemical Society. p 205-220.
Laffoon JE, Davies GR, Hoogland MLP, Hofman CL. 2012. Spatial variation of biologically available strontium isotopes $\left({ }^{87} \mathrm{Sr} /{ }^{86} \mathrm{Sr}\right)$ in an archipelagic setting: a case study from the Caribbean. J Archaeol Sci 39:2371-2384.

Lamb AL, Evans JE, Buckley R, Appleby J. 2014. Multi-isotope analysis demonstrates significant lifestyle changes in King Richard III. J Archaeol Sci 50:559-565.

Leach F, Quinn C, Morrison J, Lyon G. 2003. The use of multiple isotope signatures in reconstructing prehistoric human diet from archaeological bone from the Pacific and New Zealand. NZ J Archaeol 23:31-98.

Lee-Thorp JA, Sealy JC, van der Merwe NJ. 1989. Stable carbon isotope ratio differences between bone collagen and bone apatite, and their relationship to diet. J Archaeol Sci 16:585599.

Longin R. 1971. New method of collagen extraction for radiocarbon dating. Nature 230:241-242.

Marshall JD, Brooks JR, Lajtha K. 2007. Sources of variation in the stable isotopic composition of plants. In: Michener $\mathrm{R}$ Lajtha K, editors. Stable isotopes in ecology and environmental science. Malden, MA: Blackwell Publishing Ltd. p 22-60.

Massler M, Schour I. 1940. Studies in tooth development: the growth pattern of human teeth. J Am Dent Assoc 27:17781793.

McArthur J. 1994. Recent trends in strontium isotope stratigraphy. Terra Nova 6:331-358.

Minagawa M, Wada E. 1984. Stepwise enrichment of ${ }^{15} \mathrm{~N}$ along food chains: further evidence and the relation between $\delta^{15} \mathrm{~N}$ and animal age. Geochim Cosmochim Acta 48:1135-1140.

Montgomery J, Evans JA, Powlesland D, Roberts CA. 2005. Continuity or colonization in Anglo-Saxon England? Isotope evidence for mobility, subsistence practice, and status at West Heslerton. Am J Phys Anthropol 126:123-138.

Moorrees CFA Fanning EA., Hunt EE. 1963. Age Variation of Formation Stages for Ten Permanent Teeth. Journal of Dental Research 42:1490-1502.

Nayacakalou RR. 1955. The Fijian system of kinship and marriage. J Polynesian Soc 64:44-55.

Nier A. 1938. The isotopic constitution of strontium, barium, bismuth, thallium and mercury. Phys Rev 54:275-278.

Nunn P, Kumar R, Matararaba S, Ishimura T, Seeto J, Rayawa S, Kuruyawa S, Nasila A, Oloni B, Ram AR, et al. 2004. Early lapita settlement site at Bourewa, Southwest Viti Levu Island, Fiji. Archaeol Oceania 39:139-143.

Nunn P, Petchey F. 2013. Bayesian re-evaluation of Lapita settlement in Fiji: radiocarbon analysis of the Lapita occupation at Bourewa and nearby sites on the Rove Peninsula, Viti Levu Island. J Pacific Archaeol 4:21-34.

Nunn PD. 1994. Oceanic islands. Oxford: Blackwell.

Nunn PD. 1998. Pacific island landscapes: landscape and geological development of Southwest Pacific Islands, especially Fiji, Samoa and Tonga. Suva, Fiji: Institute of Pacific Studies, The University of the South Pacific. p xiv, 318.

Nunn PD. 2007. Climate, environment and society in the Pacific during the last millennium. Amsterdam: Elsevier.

Nunn PD. 2009. Geographical influences on settlement-location choices by initial colonizers: a case study of the Fiji Islands. Geograph Res 47:306-319.

Nunn PD. 2012. Societal disruption in the Pacific Islands from rapid sea-level fall about $\mathrm{AD}$ 1300: new evidence from northern Viti Levu Island, Fiji. J Coast Conserv 16:199-209.

Nunn PD, Ishimura T, Dickinson WR, Katayama K, Thomas FR, Kumar R, Matararaba S, Davidson J, Worthy TH. 2007. The Lapita occupation at Naitabale, Moturiki Island, central Fiji. Asian Perspect 46:96-132.

Nunn PD, Kumar R, and Matararaba S. 2003. Recent research relating to Lapita settlement in Fiji. In: Sand C, editor. Pacific archaeology: assessments and prospects. Noumeá, New Caledonia: Le Cahiers de l'Archeologie en Nouvelle Caledonie. p 183-186.

O'Connell TC, Kneale CJ, Tasevska N, Kuhnle GGC. 2012. The diet-body offset in human nitrogen isotopic values: a controlled dietary study. Am J Phys Anthropol 149:426-434. 
Oliver DL. 1989. Oceania: the native cultures of Australia and the Pacific Islands. Honolulu, Hawai'i: University of Hawai'i Press.

Olsen KC, White CD, Longstaffe FJ, von Heyking K, McGlynn G, Grupe G, Rühli FJ. 2014. Intraskeletal isotopic compositions $\left(\delta^{13} \mathrm{C}, \delta^{15} \mathrm{~N}\right)$ of bone collagen: nonpathological and pathological variation. Am J Phys Anthropol 153:598-604.

Perkins MJ, McDonald RA, van Veen FJF, Kelly SD, Rees G, Bearhop S. 2014. Application of Nitrogen and carbon stable isotopes $\left(\delta^{15} \mathrm{~N}\right.$ and $\left.\delta^{13} \mathrm{C}\right)$ to quantify food chain length and trophic structure. PLoS One 9:e93281.

Phaff B. 2012. Human dietary and mobility patterns of a prehistoric populations from Sigatoka, Fiji: a reconstruction using stable isotope analysis. Vancouver, BC, Canada: University of British Columbia.

Pollock NJ. 1992. These roots remain: food habits in islands of Central and Eastern Pacific since Western Contact. Honolulu: Honolulu Institute for Polynesian Studies.

Price TD, Blitz J, Burton J, Ezzo JA. 1992. Diagenesis in prehistoric bone: problems and solutions. J Archaeol Sci 19:513529.

Price TD, Burton JH, Bentley RA. 2002. The characterization of biologically available strontium isotope ratios for the study of prehistoric migration. Archaeometry 44:117-135.

Reitsema LJ, Vercellotti G. 2012. Stable isotope evidence for sex- and status-based variations in diet and life history at medieval Trino Vercellese, Italy. Am J Phys Anthropol 148: 589-600.

Richards MP, Hedges REM. 1999. Stable isotope evidence for similarities in the types of marine foods used by late mesolithic humans at sites along the Atlantic coast of Europe. J Archaeol Sci 26:717- 722.

Richards MP, Mays S, Fuller BT. 2002. Stable carbon and nitrogen isotope values of bone and teeth reflect weaning age at the Medieval Wharram Percy site, Yorkshire, UK. Am J Phys Anthropol 119:205-210.

Richards MP, West E, Rolett B, Dobney K. 2009. Isotope analysis of human and animal diets from the Hanamiai archaeological site (French Polynesia). Archaeol Oceania 44:29-37.

Robb KF, Nunn PD. 2014. Changing role of nearshore-marine foods in the subsistence economy of inland upland communities during the last millennium in the tropical Pacific Islands: insights from the Bā River Valley, northern Viti Levu Island, Fiji. Environ Archaeol J Hum Palaeoecol 19:1-11.

Robertson KL, Rowland NE, Krigbaum J. 2014. Effects of caloric restriction on nitrogen and carbon stable isotope ratios in adult rat bone. Rapid Commun Mass Spectrometry 28: 2065-2074.

Rodda P. 1967. Outline of the geology of Viti Levu. N Z J Geol Geophys 10:1260-1273.

Sand C. 2007. The eastern frontier: Lapita ceramics in the FijiWest Polynesia region. In: Chiu S, Sand C, editors. From Southeast Asia to the Pacific: archaeological perspectives on the Austronesian expansion and the Lapita Cultural Complex. Taipei, Taiwan: Center for Archaeological Studies Research Center for Humanities and Social Sciences, Academia Sinica. p 214-242.

Schoeninger MJ. 2010. Diet reconstruction and ecology using stable isotope ratios. A companion to biological anthropology. Wiley-Blackwell. p 445-464.

Schoeninger MJ, DeNiro MJ, Tauber H. 1983. Stable nitrogen isotope ratios of bone collagen reflect marine and terrestrial components of prehistoric human diet. Science 220:13811383.

Schoeninger MJ, DeNiro MJ. 1984. Nitrogen and carbon isotopic composition of bone collagen from marine and terrestrial animals. Geochim Cosmochim Acta 48:625-639.

Schoeninger MJ, Morre K. 1992. Bone stable isotope studies in archaeology. J World Prehistory 6:247-296.

Schroeder H, O'Connell TC, Evans JA, Shuler KA, Hedges REM. 2009. Trans-Atlantic slavery: isotopic evidence for forced migration to Barbados. Am J Phys Anthropol 139:547557.
Sharp ZD. 2007. Principles of stable isotope geochemistry. Upper Saddle River: Pearson.

Shaw B, Buckley H, Summerhayes G, Stirling C, Reid M. 2011. Prehistoric migration at Nebira, South Coast of Papua New Guinea: new insights into interaction using isotope and trace element concentration analyses. J Anthropol Archaeol 30: 344-358.

Shaw B, Buckley HR, Summerhayes G, Anson D, Garling S, Valentin F, Mandui H, Stirling C, Reid M. 2010. Migration and mobility at the Late Lapita site of Reber-Rakival (SAC), Watom Island using isotope and trace element analysis: a new insight into Lapita interaction in the Bismarck Archipelago. J Archaeol Sci 37:605-613.

Shaw BJ, Summerhayes GR, Buckley HR, Baker JA. 2009. The use of strontium isotopes as an indicator of migration in human and pig Lapita populations in the Bismarck Archipelago, Papua New Guinea. J Archaeol Sci 36:1079- 1091.

Smith AC. 1979. Flora Vitiensis nova: a new Flora of Fiji (spermatophytes only). Lawaii, Hawaii: Pacific Tropical Botanical Garden.

Stantis C, Kinaston RL, Richards MP, Davidson JM, Buckley HR. 2015. Assessing human diet and movement in the Tongan Maritime Chiefdom using isotopic analyses. PLoS One 10:e0123156.

Stantis C, Tayles N, Kinaston RL, Cameron C, Nunn PD, Richards MP, and Buckley HR. In press. Diet and subsistence in Remote Oceania: an analysis using oral indicators of diet. In: Oxenham MF, Buckley HR, editors. The Routledge handbook of bioarchaeology in Southeast Asia and the Pacific. London, UK: Routledge.

Szabó K. 2001. The reef, the beach and the rocks: an environmental analysis of mollusc remains from Natunuku, Viti Levu, Fiji. In: Clark G, Anderson A, Vunidilo T, editors. The archaeology of Lapita dispersal in Oceania. Canberra: Pandanus books. p 159-166.

Szabó K. 2009. Molluscan remains from Fiji. In: Clark G, Anderson A, editors. The early prehistory of Fiji. Canberra, Australia: ANU Press. p 183-211.

Szostek K, Mądrzyk K, Cienkosz-Stepańczak B. 2015. Strontium isotopes as an indicator of human migration - easy questions, difficult answers. Anthropol Rev 78:133-156.

Terakado Y, Shimizu H, Masuda A. 1988. Nd and Sr isotopic variations in acidic rocks formed under a peculiar tectonic environment in Miocene Southwest Japan. Contribut Mineral Petrol 99:1-10.

Tieszen LL, Boutton TW, Tesdahl K, Slade NA. 1983. Fractionation and turnover of stable carbon isotopes in animal tissues: implications for $\delta^{13} \mathrm{C}$ analysis of diet. Oecologia 57:32-37.

Trickett MA, Budd P, Montgomery J, Evans J. 2003. An assessment of solubility profiling as a decontamination procedure for the ${ }^{87} \mathrm{Sr} /{ }^{86} \mathrm{Sr}$ analysis of archaeological human skeletal tissue. Appl Geochem 18:653-658.

Tsutaya T, Yoneda M. 2015. Reconstruction of breastfeeding and weaning practices using stable isotope and trace element analyses: a review. Am J Phys Anthropol 156:2-21.

Valentin F, Bocherens H, Gratuze B, Sand C. 2006. Dietary patterns during the late prehistoric/historic period in Cikobia island (Fiji): insights from stable isotopes and dental pathologies. J Archaeol Sci 33:1396-1410.

Valentin F, Herrscher E, Petchey F, Addison DJ. 2011. An analysis of the last 1000 years human diet on Tutuila (American Samoa) using carbon and nitrogen stable isotope data. Am Antiquity 76:473-486.

van Klinken GJ. 1999. Bone collagen quality indicators for palaeodietary and radiocarbon measurements. J Archaeol Sci 26:687-695.

Veizer J. 1989. Strontium isotopes in seawater through time. Annu Rev Earth Planet Sci 17:141.

Veizer J, Buhl D, Diener A, Ebneth S, Podlaha OG, Bruckschen P, Jasper T, Korte C, Schaaf M, Ala D, et al. 1997. Strontium isotope stratigraphy: potential resolution and event correlation. Palaeogeogr Palaeoclimatol Palaeoecol 132:65-77.

Waldron T. 1994. Counting the dead: the epidemiology of skeletal populations. Chichester, NY: Wiley. 
Whipkey CE, Capo RC, Chadwick OA, Stewart BW. 2000. The importance of sea spray to the cation budget of a coastal Hawaiian soil: a strontium isotope approach. Chem Geol 168: 37-48.

Wood JW, Milner GR, Harpending HC, Weiss KM, Cohen MN, Eisenberg LE, Hutchinson DL, Jankauskas R, Čsnys G, Katzenberg MA, et al. 1992. The osteological paradox: problems of inferring prehistoric health from skeletal samples [and comments and reply]. Curr Anthropol 33:343-370.
Worthy TH, Clark G. 2009. Bird, mammal and reptile remains. In: Clark G, Anderson A, editors. The early prehistory of Fiji. Canberra, Australia: ANU Press. p 231-258.

Wutich A, Brewis A. 2014. Food, water, and scarcity: toward a broader. Anthropology of resource insecurity. Curr Anthropol 55:444-468.

Zohary T, Erez J, Berman-Frank I, Stiller M. 1994. Seasonality of stable carbon isotopes within the pelagic food web of Lake Kinneret. Limnol Oceanogr 39:1030-1043. 